\title{
Borders of Network Effects and Early Internationalization as a Latecomer Strategy
}

\author{
Sanghyun Park \\ INSEAD \\ sanghyun.park@insead.edu \\ Sungyong Chang \\ London Business School \\ schang@london.edu
}

May 29, 2021

\begin{abstract}
Scholars have examined the persistent heterogeneity of firm performance from the entry-order effect perspective. In the international business literature, this perspective has been highlighted in research on early internationalization (i.e., the born global strategy). While prior work has focused on the heterogeneity of firm characteristics and capabilities, we present a demand-side view of early internationalization by focusing on network effects. Prior theoretical work on network effects has predicted that when network effects are prominent, survival is challenging for latecomers because of the installed bases of first movers in the global market. However, we see many cases, such as the mobile instant messenger (MIM) market, where no single winner dominates the global market and where many latecomers have survived by implementing early internationalization. We build upon Brian Arthur's model of demand-side dynamics. The findings suggest that latecomers may overcome their disadvantages by pursuing early internationalization, especially when the direct network effects (i.e., social network effects) are stronger than the indirect network effects (i.e., installed base effects). The underlying rationale is that country borders often demarcate the reach of the direct network effect, limiting the power of installed bases.
\end{abstract}

Keywords: Early internationalization, network effects, social network effect, installed base, ibusiness firms 


\section{INTRODUCTION}

Why some firms do better than others is one of the fundamental questions in strategy

and international business research (Nelson, 1991; Kogut \& Zander, 1993). Studies indicate that the superior performance of some firms may persist for a long period of time (e.g., Caves \& Porter, 1977; Makadok, 1998; Rugman \& Verbeke, 2004; Berry, 2006; Johanson \& Vahlne, 2009; Berry \& Kaul, 2016). Prior work on entry-order effects indicates that latecomers tend to perform worse than incumbents (e.g., Lieberman \& Montgomery, 1988). Scholars have identified critical sources of incumbency advantages (i.e., latecomer disadvantages), such as technological leadership, complementary assets for the commercialization of innovative products, the preemption of resources, buyer switching costs, and the size of the installed base (e.g., Teece 1986; Ethiraj \& Zhu 2008; Zhu \& Iansiti, 2012).

In the international business literature, the entry-order effect has been highlighted in research on early internationalization (i.e., the born global strategy). Prior work has explored the conditions under which firms leverage an early adoption of internationalization as a growth strategy to overcome their disadvantages (e.g., Madsen \& Servais, 1997; Oviatt \& McDougall, 1995; Knight \& Cavusgil, 1996). In particular, most prior work has viewed early internationalization as a firm strategy conditioned on firm characteristics and capabilities (Dunning \& Lundan, 2008). The distinct nature of the internationalization of digital services (e.g., a strong presence of network effects) poses critical challenges to the applicability of conceptualization and theory based on firm characteristics. As Brouthers, Geisser, and Rothlauf (2016) note, the effect of the demand environment on the firm's strategic choice to expand into overseas markets is underexplored.

To address this gap, we propose a demand-based view of latecomers' early 
internationalization strategy. We focus on network effects, which are one of the critical characteristics of digital services. Network effects have an extensive influence on the optimal internationalization timing of latecomers. Under strong network effects, unless the quality of latecomers is substantially higher than that of first movers, survival is challenging for latecomers in a domestic market where first movers have already established a large installed base (Liebowitz \& Margolis, 1994; Zhu \& Iansiti, 2012). To avoid being driven out of the domestic market, instead of becoming a latecomer in the domestic market, digital service companies can pursue early internationalization into a foreign country where a similar service has yet to be introduced.

We argue that country borders may play a critical role in limiting some types of network effects because country borders deter cross-country communications and network formations. By building computational models, we explore when country borders limit the strength of network effects by classifying network effects into (1) indirect network effects (i.e., installed base effects) and (2) direct network effects (i.e., social network effects). This classification leads to our basic argument that compared to indirect network effects, the strength of direct network effects is more likely to be restricted by country borders. When direct network effects dominate indirect network effects, an early internationalization strategy may be a viable survival strategy for latecomers. The reason is that country borders shape the boundaries of social networks, which are often shaped by and limit the positive feedback between the installed base and the benefits of the service outside the focal countries. With our computational models, we provide a detailed competitive dynamic between latecomers and first movers.

The results of our computational models suggest that the relative strength of direct network effects determines when early internationalization could be a survival strategy for latecomers. When direct network effects dominate indirect network effects, latecomers can 
survive by entering countries where a similar service has yet to be introduced because country borders deter the network effects from the home country. In contrast, when indirect network effects are strong, network effects (i.e., installed base effects) are prone to spill over to other countries, thereby crowding out latecomers.

Can latecomers' early internationalization strategy help them take over global market leadership (i.e., driving out first-mover services in the home market)? Our results suggest that when direct network effects are strong, it could be difficult for latecomers with early internationalization to penetrate into a home country where first-mover services dominate. The results suggest that country borders also help first-mover services keep their market leadership in their home country. This finding highlights the paradoxical role of direct network effects in competitive dynamics: although direct network effects provide an opportunity for latecomers to survive in a foreign market, at the same time, they limit the possibility of latecomers winning in the global market.

While the literature on network effects distinguishes between indirect network effects and direct network effects (Shapiro \& Varian 1998; Lee, Song, \& Yang 2016; Zhu, Li, Valavi, \& Iansiti, 2019), only a few studies in international business (e.g., Brouthers et al., 2016; Chen, Shaheer, Yi, \& Li, 2018) distinguish between these two types of network effects and explore the divergent demand-side competition dynamics based on them. We advance our understanding of these divergent outcomes and how latecomers could strategize these different types of network effects. By doing so, we contribute to the burgeoning literature on ibusiness services, whose characteristics are distinctively based on direct network effects.

Additionally, as noted by Zander, McDougall-Covin, and Rose (2015), the born global literature is long on empirical studies but relatively short on theory and conceptualization. To address this gap, we take the opportunity to bridge the network effects literature and early internationalization literature. Our unified framework reconciles the mixed views on 
the success of latecomers in digital service markets and shows that whether the size of the installed base can deliver sustainable first-mover advantages critically depends on the type of network effect and country-level demand heterogeneity.

\section{LITERATURE REVIEW AND THEORETICAL MOTIVATION}

\subsection{First-Mover Advantage in International Business: A Demand-Side Perspec- tive}

With a close link to the entry-order effect (i.e., first-mover advantages and latecomer advantages) literature in strategic management (e.g., Lieberman \& Montgomery, 1988; Teece, 1986; Makadok, 1998; Berry, 2006; Ethiraj \& Zhu 2008; Zhu \& Iansiti, 2012), international business scholars have investigated whether firms seek early internationalization to leverage their advantages. Firms strategically choose to venture earlier in overseas markets, preempt untapped markets, and exploit their advantages. By far, the main focus of this discussion has been on supply-side dynamics, which view firm-level factors as the primary drivers of early internationalization. In particular, much of the prior work on early internationalization has assumed that internationalization is mainly conditioned on firm routines, capabilities, and experiences (e.g., Dunning \& Lundan, 2008). These characteristics include the competitive advantage of firm technology (Rennie, 1993; Madsen \& Servais, 1997), the differentiation of firm products or services (Oviatt \& McDougall, 1995; Knight \& Cavusgil, 1996), and the top management team's industry or overseas experience (McDougall, Shane, \& Oviatt, 1994; Madsen \& Servais, 1997). Similarly, scholars have highlighted that firms with specific characteristics or competitive advantages seek early internationalization as a growth strategy.

However, in research on the early adoption of internationalization, the effect of the demand environment on latecomers' strategic choice to expand into overseas markets is 
relatively underexplored. Many demand-side factors play a critical role in determining a firm's strategic decision to internationalize early. For example, demand-side factors are heterogeneous in terms of services and countries because of the differences in consumer needs and requirements (e.g., Adner \& Levinthal, 2001; Rietveld \& Eggers, 2018), the presence of the dominant player (e.g., Brouther et al., 2016), and the strength of the liability of outsidership (e.g., Vahlne \& Johanson, 2017). Notably, as country borders frequently shape and segment markets, demand heterogeneity tends to be pronounced across different countries. Identifying what factors shape such heterogeneity will be an essential step in advancing our understanding of the role of early internationalization.

\subsection{Network Effects and Latecomers' Early Internationalization}

In this study, we focus on network effects, which are one of the critical aspects of digital services. Network effects are defined as user benefits arising from the compatibility among different users, enabling them to interact or trade with other users or to use the same complementary products (Farrell \& Klemperer, 2007; Brouthers et al., 2016). Recent studies in the internationalization literature have started to examine the role of network effects in formulating global strategies (e.g., Alcácer, Cantwell, \& Piscitello, 2016; Brouthers et al., 2016; Chen et al., 2018). As Boudreau (2012) notes, digitization has increased the need for firms to harness the power of network effects to win the market competition. This new generation of service firms is saliently distinct from nondigitized service firms based on the "users as resources" perspective, one of whose core features is network effects.

Recent studies have advanced this view. Parker, Van Alstyne, and Jiang (2017) argue that this distinctive feature has inverted the locus of innovation and competition from internal activities by employees to outside activities by customers, which often happen outside the formal boundaries of firms. For example, Coviello and Joseph (2012) found that 
users contribute financial, technical, and informational inputs to influence the product development process and play a promotional role in the wider diffusion of products, including in foreign markets. This perspective on externalization has identified building a large installed base as a key success factor for digital services (Beise \& Cleff, 2004; Fuentelsaz, Garrido, \& Maicas, 2015).

However, one of the critical assumptions of theoretical and conceptual research on network effects is that the benefits from network effects grow as the installed base, i.e., the total number of users, increases. With his model, Arthur (1989) made a popular prediction that in the presence of network effects, a large installed base will produce a winner-take-all outcome, in which it is difficult for latecomers survive. However, many recent examples in the global digital service market have deviated from this prediction. A large installed base does not guarantee the emergence of a winner-take-all phenomenon in the global market. Social media and networking services, such as mobile instant messengers (MIMs) and online dating apps, are exemplary services enabling interactions between customers and encompassing products, services, or information exchange. In many cases, we observe that one service often dominates in one or a few countries but that global winners rarely emerge. Many latecomers have survived and thrived in these markets.

This deviation calls for a more systematic examination of what factors may erode the benefits brought by an installed base. Recent studies have suggested reasons why the winner-take-all phenomenon does not occur and latecomers can survive in these industries. In particular, Lee et al. (2016) and Zhu et al. (2019) note the critical role played by customers' social networks in shaping the boundaries of network effects, limiting the effects of the installed base. In this study, we argue that country borders may shape the boundaries of some types of network effects because country borders deter cross-country communications and tie formations. 
To systematically explore when network effects are bounded by country borders, we classify network effects into (1) indirect network effects (i.e., installed base effects) and (2) direct network effects (i.e., social network effects). Our main argument is that compared to indirect network effects, direct network effects are more likely to be restricted by country borders. The reason is that country borders shape the boundaries of social networks, which are often shaped by and limit the positive feedback between the installed base and the benefits of the service outside the focal countries. To shed theoretical light on this difference, we further review these two types of network effects.

2.2.1. Indirect network effects and the role of the installed base. Much of the first-mover advantage literature has focused on the roles of indirect network effects in determining competitive outcomes (Katz \& Shapiro, 1985; Adner \& Kapoor, 2010; Zhu \& Iansiti, 2012). Indirect network effects are defined as the benefits gained by customers due to the growth of the total customer base or installed base and through a larger variety of compatible complements (Katz \& Shapiro, 1985). In markets for search engines, for example, the benefits of using a search engine (e.g., Google) mainly originate from how many users are using the same engine. First, the size of the installed base is positively associated with the quality of the search engine because other users' search behavior and history produce valuable data for improving the performance of the engine's search algorithms. Second, a large installed base will attract advertisers willing to pay fees that can be reinvested to improve the quality of the engine. Undoubtedly, in these sorts of markets, control over an installed base is often crucial for winning a market (Farrell \& Saloner, 1985; Shapiro \& Varian, 1998). Indeed, as of June 2020, Google accounted for more than $92 \%$ of the market share (Statcounter, 2020), with other players having negligible market shares. 
In addition, the burgeoning literature on ecosystems is closely related to indirect network effects. Research has suggested that indirect network effects (i.e., installed base effects) are strengthened by the active role of users in introducing new innovations and products. For example, for digital services, consumers become more engaged in developing complementary products and services (Baldwin, Hienerth, \& von Hippel, 2006).

Regarding the global expansion of digital services, customer adoption depends on how many other customers in the global market use such services because customer benefits increase with the size of the installed base. In this situation, gathering a critical mass of customers engenders a large installed base, ultimately allowing the digital service provider to dominate the global market alongside only a few rivals because of the winner-takes-all dynamics (Cennamo \& Santalo, 2013). Recent studies on the global expansion of digital services (e.g., Beise \& Cleff, 2004) are based on the same view. These studies regard global expansion as a means of stimulating the gravitational force of a large installed base. Hence, a wider global presence of a digital service can be associated with a more sizable installed base. Overall, the underlying premise of this body of literature on indirect network effects is that the incremental value of one additional user is equal, regardless of who s/he is and where s/he lives (Shy, 2001).

\subsubsection{Direct network effects and the role of country borders. For many}

digital services, customers' selection of a service is influenced more by their close acquaintances, such as family and friends, than by people with whom they have no social relationships (Lee, Lee, \& Lee, 2006). Such effects are called direct network effects (Katz \& Shapiro, 1985). Direct network effects are realized when the benefits for the customer are reinforced by the number of immediate acquaintances who use the same service rather than the total number of users (Farrell \& Klemperer, 2007). This distinct characteristic of direct 
network effects strengthens the importance of the social network and its structure because the strength of such effects tends to be weak outside the network of immediate acquaintances (Lee et al., 2016). Some social networks of users mainly consist of ties among acquaintances and thus exhibit a segmented structure based on age, culture, region, or country borders. Under a segmented network structure, direct network effects may be more localized by subgroups. Because a user maintains relationships with a small number of acquaintances, it is plausible that some of those acquaintances adopt a latecomer service even when a leading service has established a huge installed base. This case is considered a local bias in service adoption (Lee et al., 2006). Over time, such a local bias may limit the possibility of a leading service's winner-take-all dominance in the global market, leaving room for latecomers to strategize such a local bias.

We argue that when the strength of direct network effects dominates the strength of indirect network effects, country borders play a significant role in shaping an optimal global strategy of digital services. In many digital services, country borders shape the boundaries of social networks for users because users' acquaintances are mostly from the same country. As noted by the World Investment Report (2016) by the United Nations Conference on Trade and Development (UNCTAD), an implicit assumption underlying the network effect dynamics of digital services is that physical borders are irrelevant. However, in many cases, a user network could be substantially heterogeneous and comprise a variety of market segments, cultural groups, or countries (Peterson, Søndergaard, \& Kara, 2018). This situation is consistent with Bruce Kogut's early observation on the globalization of the Internet in his book The Global Internet Economy (2003). He emphasizes that the Internet has borders. Specifically, he states that "... Internet technologies crashed on the shores of most countries about at the same time ... Internet technology was global, but its economic and business development was molded in the context of prevailing national institutions... 
." More recently, Ghemawat's study (2016) provides macrolevel empirical evidence on this argument, implying that user interactions on digital platforms tend to be mostly domestic. His study demonstrates that in the digital service market, country borders still matter.

In addition, direct network effects are closely related to the burgeoning literature on the nature of ibusiness firms/services and their internationalization (e.g., Brouthers et al., 2016; Chen et al., 2018). In their pioneering work, Brouthers et al. (2016) distinguish ibusinesses from other types of e-businesses (i.e., a broad category of products/services based on the Internet). They define ibusinesses as digital services that create customer value by channeling the input and interaction between users, implying that direct network effects play the main role in shaping potential adopters' choice between different services. Social networking services such as instant messengers and online dating apps are exemplary cases because these services create value by providing a digital platform for users to interact with one another. Chen et al. (2018) provide systematic evidence that direct network effects play a more significant role in ibusiness and that for such services, the impact of the size of the installed base is limited.

\subsection{Early Internationalization as a Survival Strategy for Latecomers}

As noted above, under strong network effects, it is difficult for a latecomer digital service to survive competition with a first-mover digital service. As indicated by prior work, unless the quality of the latecomer service significantly outperforms that of the first-mover service, it will be challenging for the latecomer service to survive this competition (e.g., Zhu \& Iansiti, 2012, Lee et al., 2016). If latecomers encounter difficulties (e.g., the nature of the service or technical limits) in differentiating their quality from that of first-mover services, what could be a survival strategy for latecomers in the digital service industry? While early internationalization has not been viewed as a viable survival 
strategy in the international business setting, we argue that pursuing early

internationalization into an untapped foreign market could be an alternative to becoming a latecomer service in the domestic market. We explore the conditions under which a latecomer digital service can survive and thrive in competition with a first mover.

To explore such conditions, we first investigate how the relative strength of direct network effects (over indirect network effects) determines the optimal latecomer strategy by

comparing (1) an early internationalization strategy and (2) a late domestic entry strategy. To produce a more seasoned view, we analyze how quality heterogeneity shapes the role of the relative strength of direct network effects in determining the optimal latecomer strategy. As shown by Ethiraj and Zhu (2008), the quality of latecomers' products/services tends to be higher than that of first movers' products/services. To reflect this possibility, we explore the quality advantage of latecomers as a boundary condition under which early internationalization could be a viable survival strategy in competition.

\section{MOTIVATION CASE: EARLY INTERNATIONALIZATION OF NAVER LINE IN THE MOBILE INSTANT MESSENGER MARKET}

A MIM is a real-time communication tool that enables users to connect with coworkers, friends, and family through the instantaneous transmission of text-based messages via a mobile device (Davey \& Envall 2004; Zhou \& Lu, 2011). The history of competition between the two South Korean MIM products (Kakao Talk vs. NHN Line) shows that early internationalization could be a viable survival strategy for latecomers. In March 2010, Kakao made headway by introducing its MIM service, Kakao Talk, in South Korea. The Kakao Talk messenger has enjoyed the advantages of being the first mover in the South Korean MIM market by preempting a large user network base. Kakao Talk succeeded in grabbing the dominant market share within months of its introduction and has continued 
to hold market leadership, with a market share of $94.4 \%$ of the total time spent on mobile messengers in South Korea and 35.2 million active South Korean users as of February 2016.

Meanwhile, Naver Line was one of the latecomers in the South Korean MIM market. When Naver introduced its Naver Line messenger in February 2011 (i.e., 11 months after the launch of Kakao Talk), Naver Line faced severe difficulties in expanding its user base due to Kakao Talk's strong network effects in South Korea. Unlike other latecomers in the South Korean market, Naver promptly changed its trajectory to pursue early internationalization (i.e., focusing on the Japanese market and giving up the South Korean market). In June 2011, Naver introduced its MIM product, Naver Line, to Japan, where no MIM service had yet to be introduced. Additionally, the Japanese MIM user network was sparsely connected with the Korean MIM user network because of the differences in language and culture between Japan and South Korea. Naver Line took advantage of the border of the network effects between the two countries. Naver Line entered the Japanese market as an early mover and subsequently became the dominant service. As of 2019, the Naver Line was still the dominant player, with 83 million users (out of the 120 million potential users constituting the population of Japan).

Based on its success in Japan, Naver Line further expanded its businesses starting in Southeast Asia, and it gained more than 300 million global users. In 2016, Naver Line became the market leader in Thailand, Taiwan, Indonesia, and Japan. In 2019, Naver Line held the third largest user base in the global MIM market, with a presence in over 193 countries and 300 million users worldwide, following WhatsApp (900 million users) and WeChat (500 million users). Although Naver Line has built a larger installed base in the global market, Kakao Talk has succeeded in securing its market leadership in South Korea; this situation shows that it has not been easy for Naver Line to erode the strong presence of Kakao Talk in South Korea. 


\section{MODEL}

We develop a computational model to examine the conditions under which latecomers can overcome the first-mover advantage in the context of global competition. In particular, we build upon Brian Arthur's model of increasing returns to adoption (1989), which captures how competition under increasing returns to adoption (e.g., network effects) may result in a "winner-take-all" outcome, where a single technology corners the market and others cannot survive. Authur's model has been adopted for subsequent theoretical work in the strategy literature (e.g., Lee et al., 2006; Zhu \& Iansiti, 2012; Lee et al., 2016;

Lamberson \& Page, 2017; Denrell \& Liu, 2021). Lee et al. (2016, pp.1632-1633) summarize the essence of the Arthur model as follows: "When two or more incompatible products compete for customers, the product with the larger installed base magnifies customer benefits. According to Arthur, the leading product with more benefits will attract more customers, whereas lagging products ... may lose their market shares. Over time, this self-reinforcing process, or positive feedback process, will amplify the advantage for the leading firm with the market share... ". Specifically, first movers are more likely to benefit from increasing returns to adoption because they tend to have a greater market share than latecomers (e.g., Liebermand \& Montogomery, 1988).

We extend Arthur's model in two ways. Following recent studies (e.g., Suarez, 2005; Afuah, 2013; Lee et al., 2016), we first distinguish between direct and indirect network effects, whereas the Arthur model considers only the latter. We examine how the relative strength of direct network effects compared to indirect network effects shapes adoption dynamics. Second, while Arthur's model involves only one country (or a single market), our model involves two countries (two markets) - the home country and a foreign country where a first mover and a latecomer compete for consumers. 
We explore the performance implications of two internationalization strategies: (1) late domestic entry and (2) early internationalization. First, late domestic entry refers to a strategy in which a latecomer first enters a home country where a first mover's service has already been introduced. This strategy corresponds to a traditional internationalization strategy: firms first introduce their products/services in their domestic markets and subsequently enter foreign markets (e.g., Johanson \& Vahlne, 1977). Second, in this study, early internationalization refers to a strategy in which a latecomer first chooses to enter a foreign country before introducing its service to the home country. This strategy can be a type of a born global strategy because many born global firms internationalize their services from or near their founding (Knight \& Cavusgil, 1996; Oviatt \& McDougall, 1995; Knight \& Cavusgil, 2004).

In the baseline model, we assume that two digital services are symmetric in terms of quality, price, and other features except for the entry timing. Additionally, the two countries have identical sizes and consumer preferences. We deliberately assume this symmetry to focus on the impact of the strength of direct network effects on adoption dynamics while controlling other potential confounders. These symmetry assumptions with regard to services and countries will be relaxed in the extended model and sensitivity checks.

\subsection{Two Internationalization Strategies}

In our model, two digital services, $F$ (first mover) and $L$ (latecomer), compete in two countries: countries $A$ (home country) and $B$ (foreign country). The first mover introduces its service in the domestic market at $t_{F}$, and the latecomer chooses to enter either the domestic market (i.e., late domestic entry) or the foreign market (i.e., early internationalization) at $t_{L}$, where $t_{L}>t_{F}$. We assume that the first mover (and the 
latecomer) introduces its service to the other country after period $t_{E}$. The first mover enters the foreign country at $t_{F}+t_{E}$. When the latecomer follows early internationalization (late domestic entry), it introduces its service to the home country (the foreign country) at $t_{L}+t_{E}$.

In the baseline model, we use $t_{F}=0, t_{L}=1$, and $t_{E}=3$. The first mover introduces its service in the domestic market at $t=0$ and enters the foreign country at $t=3$. When the latecomer pursues the late domestic entry strategy, it enters the domestic country at $t=1$ and internationalizes its service to the foreign country at $t=4$. In this case, the entry timing of the latecomer lags one period behind that of the first mover in both countries. When the latecomer follows the early internationalization strategy, it first enters the foreign country at $t=1$ and introduces its service in the home country at $t=4$. In this case, the entry time of the latecomer is two periods ahead of that of the first mover in the foreign country, while it lags four periods behind in the home country. Later, we explore other parameter sets in the sensitivity analysis.

\subsection{Adoption Rules for Consumers}

Each country has $N$ consumers. Each consumer's adoption of a digital service is determined by three factors: (1) consumer reluctance, (2) network effects, and (3) quality. Specifically, consumer $j$ 's willingness to adopt service $k \in(F, L)$ at time $t$ in country $i \in(A, B)$ is as follows:

$$
U_{i j k t}=\gamma \omega_{i k t}-R_{j}+Q_{k}
$$

where $\gamma>0$ is a constant ${ }^{1}, \omega_{i j t}$ represents the network effects of service $j$ in country $i$ at time $t, R_{j}$ represents consumer $j$ 's reluctance to adopt a digital service, and $Q_{k}$ is the quality of service $k$. Lee et al. (2016) noted that "reluctance can be regarded as a (psychological) cost, whereas the network effects represent customer benefits." We assume 
that $R_{j}$ follows a normal distribution with $N(\mu, \sigma)$ based on the widely used framework of adopter categories (Rogers, 1995). When $U_{i j k t}>0$, service adoption occurs. We allow users to switch services when the other service provides greater benefits than the current service.

Note that when consumers have a negative reluctance $\left(R_{j}<0\right)$, they adopt a digital service without network effects (i.e., the early adopter).

In the baseline model, we assume that the two digital services are identical in their quality $\left(Q_{F}=Q_{L}\right)$. Later, we incorporate the latecomer's quality advantage $\left(Q_{F}<Q_{L}\right)$ because several studies have noted that the quality of latecomers' products/services tends to be higher than that of first movers' products/services (e.g., Liebowitz, 2002; Liebowitz \& Margolis, 2001; Ethiraj \& Zhu, 2008; Zhu \& Iansiti, 2012; Lee et al., 2016).

\subsection{Network Effects}

Based on recent work in strategy (e.g., Suarez 2005; Afuah, 2013; Lee et al., 2016), in our model, network effects consist of both direct network effects and indirect network effects. For simplicity, we assume that direct network effects are proportional to the number of users in the focal country and that indirect network effects are proportional to the total number of users in the global market (i.e., the sum of the numbers of users in countries A and B) ${ }^{2}$. We vary the strength of direct network effects with a tunable parameter, $\alpha$, while controlling indirect network effects. Specifically, the network effects of service $k$ in markets $A$ and $B$ at time $t$ are as follows:

$$
\begin{array}{r}
\omega_{A k t}=\alpha n_{A k(t-1)}+\left(n_{A k(t-1)}+n_{B k(t-1)}\right) \text { and } \\
\omega_{B k t}=\alpha n_{B k(t-1)}+\left(n_{A k(t-1)}+n_{B k(t-1)}\right),
\end{array}
$$

where $n_{A k(t-1)}$ represents the number of users of service $k$ in market $A$ at $t-1$. Here, $\alpha$ represents the strength of direct network effects $(\alpha \in[0, \infty))$. When $\alpha=0$, only indirect 
network effects exist. The network effects of service $\mathrm{k}$ are determined by the total number of users in the two countries $\left(n_{A k(t-1)}+n_{B k(t-1)}\right)$. Thus, for a given service, there is no difference in network effects between the countries $\left(\omega_{A k t}=\omega_{B k t}\right)$. When $\alpha>0$, the strength of the network effects differs by country. For example, assume that service $k$ has ten users in country $A$ and five users in country $B$. When $\alpha=1$, the network effects for consumers in country $A\left(\omega_{A k t}\right)$ are $10+(10+5)=25$, while those for consumers in country $B\left(\omega_{B k t}\right)$ are $5+(10+5)=20$. Because there are more users in country $A$, the network effects in country $A$ are stronger than those in country $B\left(\omega_{A k t}>\omega_{B k t}\right)^{3}$.

All parameter values are specified in Table 1, and further details on our implementation of the model are described in Table 1 and Appendix A.

[Insert Table 1 about here]

\section{RESULTS}

To examine how and when early internationalization is effective for the latecomer, we run simulation experiments. First, we provide the results of the baseline model. In the baseline model (section 5.1-5.2), we examine the role of direct network effects in determining the viability of early internationalization as a survival strategy for the latecomer. We vary the strength of direct network effects $(\alpha)$ from 0 (i.e., only indirect network effects exist) to 3 (direct network effects are three times greater than indirect network effects). Here, we assume that the two competing services are identical in their quality $\left(Q_{F}=Q_{L}\right)$.

As shown by Ethiraj and Zhu (2008), the quality of latecomers' products/services tends to be higher than that of first movers' products/services. In the extended model (section 5.3), we relax the assumption of identical quality. We extend our model to incorporate the latecomer's quality advantage $\left(Q_{F}<Q_{L}\right)$ to explore the boundary conditions under which 
the latecomer prefers late domestic entry. We consider the quality advantage of the latecomer's service as a boundary condition for our analysis. Finally, we check the robustness of our main findings in the sensitivity analysis (section 5.4).

\subsection{Baseline Model: Adoption Dynamics under Different Entry Strategies of the Latecomer $(\alpha=2)$}

To illustrate how the two internationalization strategies (late domestic entry strategy and early internationalization strategy) determine competitive outcomes, we present two typical cases (i.e., typical simulation runs). Figure 1 shows a typical case of failure in which the latecomer introduces its service in the home country one period later than the first mover (the first mover introduces its service at $t=0$ ). In Figure $1 \mathrm{~A}$, at the time of the latecomer's entry $(t=1)$, the first mover has attracted $9.0 \%$ of the consumers in the home country's (country A's) population. This first mover's early lead in the number of users prevents the latecomer from attracting consumers in the home country (country $A$ ). Thus, the latecomer cannot secure a positive market share in the home country over the long run. When the latecomer follows late domestic entry, it enters the foreign country (country $B$ ) at $t=4$, while the first mover introduces its service at $t=3$ (Figure 1B). Similarly, in Figure 1B, the first mover has attracted $97.4 \%$ of the population at the time of the latecomer's entry into the foreign country. Again, this first mover's lead in the foreign country prevents the latecomer from attracting consumers in the foreign country (country $B)$, and the latecomer's market share remains at zero. In summary, the latecomer pursuing the late domestic entry strategy cannot secure a positive market share in the global market (Figure 1C).

\section{[Insert Figure 1 about here]}

Figure 2 illustrates a successful case in which the latecomer survives through early 
internationalization. Figure 2B shows that the latecomer with early internationalization can attract consumers in the foreign country (country $B$ ) where the first mover's service has yet to be introduced. When the first mover enters the foreign country at $t=3$, the latecomer attracts $33.3 \%$ of the population. Although the global market share (48.8\%) of the first mover is approximately three times larger than that of the latecomer $(16.5 \%)$, the first mover fails to attract consumers in the foreign country. As a result, the latecomer takes the entirety of the market share in the foreign country at $t=3$, while the first mover's market share becomes zero. However, in the home country (country $A$ ), the latecomer cannot secure a positive market share. When the latecomer enters the home country at $t=4$, approximately $97 \%$ of the population has adopted the first mover's service. The first mover's lead in the home country prevents the latecomer from attracting consumers in this country. Thus, the resulting adoption dynamics at the global level (Figure 2C) show that the first mover's early lead in the global market share is attenuated after $t=3$. Consequently, the two incompatible services persist in the global market (Figure 2C).

[Insert Figure 2 about here]

\subsection{Mechanism: Why Can Early Internationalization Be a Survival Strategy for the Latecomer When the Direct Network Effect Is Strong?}

To more systematically understand these results, we run more simulations by varying the strength of direct network effects $(\alpha)$. We vary the strength of direct network effects from $\alpha=0$ to $\alpha=3$. When $\alpha=0$, there are no direct network effects. As $\alpha$ increases, the direct network effects become prominent compared to the indirect network effects. For example, when $\alpha=3$, the direct network effects are three times stronger than the indirect network effects for a given number of users. For a given strength of direct network effects, we measure the global market share of the first mover and the latecomer by counting the 
number of users at $t=20$. All reported results are calculated by averaging 10,000 competition runs.

Figure 3 shows how the strength of direct network effects affects the performance implications of each internationalization strategy. The vertical axis of these figures represents the global market share at $t=20$. Figure $3 \mathrm{~A}$ shows that the latecomer cannot secure its foothold in the market regardless of the strength of direct network effects ${ }^{4}$. In contrast, Figure 3B shows that there exists a shared market regime where the latecomer's service can persist in the global market even though the first-mover advantage is present. The latecomer can secure a positive global market share $(50 \%)$ at $t=20$, which is comparable to the first mover's market share.

More importantly, we find that the strength of direct network effects is a boundary condition for early internationalization to become a viable survival strategy. Specifically, Figure 3B shows that early internationalization is viable only when $\alpha$ is equal to or greater than 2 ; otherwise (i.e., $\alpha<2$ ) the latecomer cannot survive regardless of its internationalization strategy. This finding implies that strong network effects do not necessarily favor the first mover. The strong direct network effects in the foreign country may buffer the first-mover advantage (i.e., having greater global market share), and this buffer effect flows through indirect network effects. On the other hand, when direct network effects are less prominent, the first mover may overcome the latecomer's early lead in the number of users in the foreign country by providing greater indirect network effects.

\section{[Insert Figure 3 about here]}

Why is early internationalization effective only when direct network effects are prominent? To answer this question, in Figure 4, we compare the network effects of the two digital services in each country. The vertical axis of Figure 4 represents network effects, and 
the horizontal axis represents the strength of direct network effects. In particular, we measure network effects, especially when competition initially occurs in each country, because the early gap in network effects determines which service will win that country. For the home country, the strength of network effects for each service is measured when the latecomer enters the home country $(t=4)$. For the foreign country, we measure the strength of the network effects of each service when the first mover enters the foreign country $(t=3)$.

[Insert Figure 4 about here]

Figure 4A shows that the ability of the first mover to penetrate the foreign country depends on the strength of direct network effects. For consumers in the foreign country, the strength of the network effects for both services increases with the strength of direct network effects because they attract more users. When direct network effects are weak $(\alpha<2)$, the first mover's service provides greater network effects than the latecomer's service in the foreign country. The reason is that the first mover has attracted more users at the global level than the latecomer, and thus, the first mover's indirect network effects dominate the latecomer's network effects. However, when direct network effects are strong ( $\alpha \geq 2$ ), the strength of the network effects of the latecomer exceeds those of the first mover. The reason is that the network effects of the latecomer consist of direct network effects, whereas those of the first mover consist of indirect network effects from users in the home country. As $\alpha$ increases, consumers in the foreign country are influenced more by users in the same country than by those in the other country. Thus, even when the latecomer lags behind the first mover in terms of global market share, the strong direct network effects of the latecomer can buffer the indirect network effects of the first mover in the foreign country. We also find that the crossover point $(\alpha=2)$ is close to the critical point in Figure 3. 
Figure 4B shows that for home country consumers, the strength of the network effects of the first mover is always greater than that of the network effects of the latecomer at $t=4$ regardless of the strength of direct network effects. When $\alpha<2$, the network effects of the first mover increase with the strength of the direct network effects because the first mover can attract more users before the latecomer's entry and each user generates greater direct network effects. There is a sudden drop at $\alpha=2$ because the first mover cannot attract consumers in the foreign country when $\alpha \geq 2$. In contrast, the latecomer provides positive network effects only when $\alpha \geq 2$, but its network effects are constant at approximately 1,000. The reason is that the latecomer's network effects consist of indirect network effects from users in the foreign country, which are fixed and independent of the strength of direct network effects. As a result, the strength of the network effects for the first-mover service is greater than that of the network effects for the latecomer's service, and the latecomer cannot penetrate the home country regardless of the strength of the direct network effects.

Overall, these findings validate our argument that an early internationalization strategy becomes viable for the latecomer only when direct network effects are strong. When $\alpha \geq 2$, the latecomer can secure a nonzero market share by preempting the foreign country through early internationalization, resulting in the coexistence of competing services at the global level. There is no survival strategy for the latecomer outside of that regime unless it has a quality advantage and country borders do not bound the first mover's advantage.

\subsection{Impact of the Latecomer's Quality Advantage}

In the baseline model, we assume that the services of the first mover and the latecomer are identical in quality. As shown by Ethiraj and Zhu (2008), the quality of latecomers' products/services tends to be higher than that of first mover's products/services. To reflect this possibility, we incorporate the latecomer's quality advantage as the extent to which the 
latecomer's service offers greater benefits than the first mover's service (i.e., $Q_{L}-Q_{F}$, where $\left.Q_{L}>Q_{F}\right)$.

Figure 5 shows the impact of the latecomer's quality advantage on its global market share. The vertical axis represents the degree of the latecomer's quality advantage $\left(Q_{L}-Q_{F}\right)$, while the horizontal axis represents the strength of direct network effects $(\alpha)$. Figure 5A demonstrates that competition always generates winner-take-all outcomes (either the first mover takes the entirety of the global market share or the latecomer takes the entirety of the global market share) when the latecomer pursues the late domestic entry strategy. Additionally, the winner is determined by the relative strength of direct network effects compared to the latecomer's quality advantage. Consistent with previous studies (Zhu \& Iansiti, 2012; Lee et al., 2016), the latecomer can overtake the first mover in both markets when the latecomer's quality advantage is more prominent than network effects (the upper-left corner of the figure; $\alpha \leq 1.1$ and $Q_{L}-Q_{F} \geq 95$ ). As $\alpha$ increases, the latecomer needs a greater degree of quality advantage to win both markets. For example, when $\alpha=0$, the latecomer's quality advantage should be equal to or greater than 95 to dominate the first mover, whereas when $\alpha=1$, it should be at least 185 .

\section{[Insert Figure 5 about here]}

Figure 5B shows that when the latecomer chooses the early internationalization strategy, there are three regions: (1) a region where the latecomer cannot survive, (2) a region where the latecomer with early internationalization can survive, and (3) a region where the latecomer can dominate both countries. First, in the bottom-left corner of the figure ( $\alpha \leq 2$ and $\left.Q_{L}-Q_{F} \leq 20\right)$, the latecomer cannot survive. The latecomer's quality advantage is not sufficient to survive under weak direct network effects. However, as the latecomer's quality advantage increases, the range of this region decreases. Second, in the 
upper-left region of the figure $\left(\alpha \leq 0.6\right.$ and $\left.Q_{L}-Q_{F} \geq 25\right)$, the latecomer with early internationalization can dominate both countries. By providing a higher-quality service, the latecomer can attract consumers faster and overtake the first mover's market share in the global market. Furthermore, as direct network effects are weak, the latecomer can exploit its lead in the global market share in the home country. Third, early internationalization results in a shared market regime for the remaining region. The latecomer takes the entirety of the market share of the foreign country, and the first mover takes the entirety of the market share of the home country. The latecomer's quality advantage is insufficient to overcome the direct network effects of the first mover's service in the home country. Thus, the first mover dominates the home country, while the latecomer dominates the foreign country.

Figure 6 illustrates the latecomer's optimal internationalization strategy. We find that early internationalization is not always optimal for the latecomer. Instead, the optimal strategy is contingent upon both the strength of direct network effects and the quality advantage of the latecomer. In particular, when the direct network effects are moderately strong $(0.6 \leq \alpha \leq 1.2)$, there is a region where the latecomer with late domestic entry wins both markets, while the latecomer with early internationalization dominates only the foreign country. The underlying intuition is that when direct network effects are prominent $(\alpha \geq 0.6)$, the latecomer with a quality advantage may prefer to compete with the first mover in the early stage of adoption, where the first mover's lead in market share is still limited. In contrast, when the latecomer pursues early internationalization, its quality advantage may be insufficient to overcome the strong direct network effects of the first mover in the home country.

\section{[Insert Figure 6 about here]}

Figure 7 shows that the quality advantage required for the latecomer to become a 
global winner (i.e., take the entirety of the global market share) increases as the strength of direct network effects becomes larger. This figure shows that early internationalization while providing a chance to survive - may limit the latecomer's ability to exploit its quality advantage, especially when direct network effects are prominent $(\alpha \geq 0.6)$. As the strength of such effects increases, the required quality advantage increases much faster for the early internationalization strategy than for late domestic entry. For example, when $\alpha=2$, for the latecomer with early internationalization to win both markets, its quality advantage should be equal to or greater than 2,000. In contrast, a quality advantage equal to 300 is sufficient for the latecomer to win both markets when it pursues the late domestic entry strategy. The underlying intuition is that early internationalization allows the first mover to attract more consumers in the home country before the latecomer's entry and the strong direct network effects in the home country limit the latecomer's ability to penetrate the home country from the foreign country.

[Insert Figure 7 about here]

\subsection{Sensitivity Analyses}

In the baseline model, we assume that the two countries are identical in their service preferences (i.e., reluctance) and market sizes. Our key finding is that early internationalization may help the latecomer survive under strong direct network effects. In this section, we show that this finding is robust to the symmetry assumption and model specifications.

First, we relax the assumption that consumers in the two countries have an identical distribution (of consumers) of reluctance toward the two digital services. For example, consumers in the foreign country may prefer the latecomer's service, while consumers in the home country may prefer the first mover's service. In this case, it could be more difficult 
for the first mover to penetrate the foreign country because the latecomer (with early internationalization) dominated the foreign country. In Appendix C, we show that while consumer heterogeneity across different countries affects the viability of the latecomer's early internationalization strategy, our main finding is robust. Second, countries may differ in population, and heterogeneity in market size affects indirect network effects. In Appendix D, we show that while differences in market sizes (i.e., country market sizes) affect the viability of the latecomer's early internationalization strategy, our main finding is robust.

Next, we examine whether our key finding is robust to different specifications of network effects. While a linear model of network effects is widely adopted and empirically supported (e.g., Arthur, 1989; Van Hove, 2016a, 2016b; Zhang et al., 2015), a logarithmic functional form is often adopted to capture decreasing marginal utility (e.g., Briscoe, Odlyzko, \& Tilly, 2006; Ohashi, 2003; Zhu \& Iansiti, 2012). In Appendix E, Panel A shows that our key finding is robust to different functional forms of network effects. Additionally, as noted above, our control parameter, $\alpha$, increases not only the strength of direct network effects but also the net size of network effects. Panel B shows that controlling the net size of network effects does not affect our findings.

Finally, we check the effect of model parameters, including the timing of entry $\left(t_{L}\right)$ and internationalization $\left(t_{E}\right)$ (Appendix F) and the reluctance distribution (Appendix G). Again, our key finding is robust to the parameter values, and the survival regime for the latecomer with early internationalization expands or shrinks.

\section{DISCUSSION AND CONCLUSIONS}

This study focuses on the competitive dynamics between first movers and latecomers in the global competition of the digital service industry. To explore these competitive dynamics, we attempt to integrate two different research streams: the literature on network 
effects and the literature on the internationalization of digital services. Specifically, we explore the role of early internationalization as a latecomer strategy. We believe that our study well complements prior work and helps scholars gain a broader understanding of competitive dynamics because previous studies have focused on first movers' motivation for early internationalization (e.g., Stallkamp \& Schotter, 2019). Additionally, we contribute to the literature by introducing a new methodology for studying the roles of network effects in strategizing internationalization timing. This gap in the literature primarily stems from the bewildering complexity in competitive dynamics under demand-side increasing returns. Many real-world network effects consist of different types of network effects. The composition of network effects may have an influence on competitive dynamics in an incomprehensible way, potentially confounding researchers and making it difficult to draw an unambiguous conclusion. Using the methodological strategy developed in strategic management and economics (Arthur, 1989; Zhu \& Iansiti, 2012; Lee et al., 2016), we confront the daunting challenge described herein. We believe that the theoretical tools adopted here can be useful in studying many other internationalization phenomena.

We believe that this study is the first simulation-based attempt to investigate how latecomer decisions regarding internationalization timing can affect the survivability and performance of latecomers in the digital service industry. Prior research has tended to depend on insights from conceptual work with in-depth case studies, and few international business researchers have developed theoretical models on competitive dynamics in the presence of network effects. Our computational model provides a good complement to these case studies and empirical findings in the literature. Moreover, prior researchers have had difficulty identifying the individual effects of the composition of network effects and demand heterogeneity because these major attributes of the demand environment were intertwined in an abstruse fashion. Using computational simulations, we separate out the 
effects of each demand environment variable. Our model does not include the social network structure of consumers, which is a promising yet underexplored area of research (Chen et al., 2018). Prior work has noted that social network structure shapes the boundaries of direct network effects (Lee et al., 2006; Lee et al., 2016; Zhu et al., 2019). Thus, explicitly modeling the structure of social networks (e.g., the degree of separation, connectivity, or clustering) will give us a chance to see the more fundamental underlying dynamics of customer adoption. In our model, we could not include the structure of social networks because our focus was on competitive dynamics that are already full of nonlinear and complex relationships. This simplifying assumption allows us to focus on the main effect of the latecomer's internationalization timing on its survivability and performance.

Additionally, as frequently noted, in reality, first movers will strive to prevent market catch-up by latecomers by aggressively investing in research and development (R\&D) or implementing a rapid internationalization strategy. This assumption may be relaxed in future work. It would be particularly interesting from our perspective to clarify the different strategic behaviors of first movers in their efforts to prevent market catch-up. 


\section{FOOTNOTES}

1. Scaling parameter $\gamma$ helps us fine tune the model to avoid two extreme cases. On the one hand, when the network effects at the initial stage are too small compared to reluctance, the adoption dynamics may not be initiated, resulting in underadoption. On the other hand, when the network effects are too strong, the first mover may corner both markets even before the entry of the latecomer. Although these extreme cases may exist in reality, we choose to avoid them because they are rather trivial and theoretically uninteresting. We later explore different functional forms of network effects in the sensitivity analysis (Appendix D).

2. Despite its simplicity, recent empirical papers find that for an individual's utility, a linear function of network size fits the data surprisingly well (Van Hove, 2016a, 2016b; Zhang et al., 2015).

3. Note that the net size of the network effects increases with $\alpha$ as we control the size of indirect network effects. We later extend our analysis to control the net size of the network effects.

4. As argued in previous studies (Lieberman and Montgomery 1988; Teece 1986; Ethiraj and Zhu 2008; Zhu and Iansiti, 2012), a latecomer without a quality advantage cannot survive through the late domestic entry strategy regardless of the strength of direct network effects. 


\section{REFERENCES}

Adner, R. \& Kapoor, R., (2010). Value creation in innovation ecosystems: How the structure of technological interdependence affects firm performance in new technology generations. Strategic Management Journal, 31(3), pp.306-333.

Adner, R. \& Levinthal, D., (2001). Demand heterogeneity and technology evolution: implications for product and process innovation. Management Science, 47(5), pp.611-628.

Afuah, A. (2013). Are network effects really all about size? The role of structure and conduct. Strategic Management Journal, 34(3), 257-273.

Alcácer, J., Cantwell, J., \& Piscitello, L. (2016). Internationalization in the Information Age: A New Era for Places, Firms, and International Business Networks?. Springer.

Arthur, W. B. (1989). Competing technologies, increasing returns, and lock-in by historical events. The Economic Journal, 99(394), 116-131.

Baldwin, C., Hienerth, C., \& Von Hippel, E. (2006). How user innovations become commercial products: A theoretical investigation and case study. Research Policy, 35(9), 1291-1313.

Berry, H. (2006). Leaders, laggards, and the pursuit of foreign knowledge. Strategic Management Journal, 27(2), 151-168.

Berry, H., \& Kaul, A. (2016). Replicating the Multinationality-Performance Relationship: Is there an S-curve?. Strategic Management Journal, 37(11): 2275-2290

Beise, M., \& Cleff, T. (2004). Assessing the lead market potential of countries for innovation projects. Journal of International Management, 10(4), 453-477.

Boudreau, K. J. (2012). Let a thousand flowers bloom? An early look at large numbers of software app developers and patterns of innovation. Organization Science, 23(5), 1409-1427.

Briscoe, B., Odlyzko, A., \& Tilly, B. (2006). Metcalfe's law is wrong-communications networks increase in value as they add members-but by how much?. IEEE Spectrum, 43(7), 34-39.

Brouthers, K. D., Geisser, K. D., \& Rothlauf, F. (2016). Explaining the internationalization of ibusiness firms. Journal of International Business Studies, 47(5), 513-534.

Caves, R. E., \& Porter, M. E. (1977). From entry barriers to mobility barriers: Conjectural decisions and contrived deterrence to new competition. The Quarterly Journal of Economics, 241-261.

Cennamo, C., \& Santalo, J. (2013). Platform competition: Strategic trade-offs in platform markets. Strategic Management Journal, 34(11), 1331-1350.

Chen, L., Shaheer, N., Yi, J., \& Li, S. (2018). The international penetration of ibusiness firms: Network effects, liabilities of outsidership and country clout. Journal of International Business Studies, 1-21.

Coviello, N. E., \& Joseph, R. M. (2012). Creating major innovations with customers: Insights from small and young technology firms. Journal of Marketing, 76(6), 87-104.

Davey, T., \& Envall, A. (2004). "Instant Messaging: Functions of a New Communicative Tool", Anthropology 427 Doing Things With Words, Master thesis. 
Denrell, J., \& Liu, C. (2021). When Reinforcing Processes Generate an Outcome-Quality Dip. Organization Science.

Dunning, J. H., \& Lundan, S. M. (2008). Multinational Enterprises and the Global Economy. Edward Elgar Publishing.

Ethiraj, S. K., \& Zhu, D. H. (2008). Performance effects of imitative entry. Strategic Management Journal, 29(8), 797-817.

Farrell J, Klemperer P. (2007). Coordination and lock-in: Competition with switching costs and network effects. Handbook of Industrial Organization (Volume 3), Armstrong M, Porter R (eds). Elsevier: New York. 1967-2072.

Farrell, J., \& Saloner, G. (1985). Standardization, compatibility, and innovation. The RAND Journal of Economics, 70-83.

Fuentelsaz, L., Garrido, E., \& Maicas, J. P. (2015). Incumbents, technological change and institutions: How the value of complementary resources varies across markets. Strategic Management Journal, 36(12), 1778-1801.

Ghemawat, P. (2016). The laws of Globalization and Business Applications. Cambridge University Press.

Johanson, J., \& Vahlne, J. E. (1977). The internationalization process of the firm-a model of knowledge development and increasing foreign market commitments. Journal of International Business Studies, 8(1), 23-32.

Johanson, J., \& Vahlne, J. E. (2009). The Uppsala internationalization process model revisited: From liability of foreignness to liability of outsidership. Journal of International Business Studies, 40(9), 1411-1431.

Katz M. L., \& Shapiro C. (1985). Network externalities, competition, and compatibility. American Economic Review 75: 424-440.

Knight, G. A., \& Cavusgil, S. T. 1996. The born global firm: A challenge to traditional internationalization theory. Advances in International Marketing, 8: 11-26.

Knight, G.A. \& Cavusgil, S.T., (2004). Innovation, organizational capabilities, and the born-global firm. Journal of International Business Studies, 35(2), pp.124-141.

Kogut, B., \& Zander, U. (1993). Knowledge of the firm and the evolutionary theory of the multinational corporation. Journal of International Business Studies, 24(4), 625-645. Kogut, B. M. (Ed.). (2003). The Global Internet Economy. MIT Press.

Lamberson, P. J., \& Page, S. E. (2018). First mover or higher quality? Optimal product strategy in markets with positive feedbacks. Journal of Economics 85 Management Strategy, 27(1), 40-52.

Lee E., Lee J., \& Lee J. (2006). Reconsideration of the winner-take-all hypothesis: complex networks and local bias. Management Science 52: 1838-1848.

Lee, J., Song, J., \& Yang, J. S. (2016). Network structure effects on incumbency advantage. Strategic Management Journal, 37(8), 1632-1648.

Lieberman, M. B., \& Montgomery, D. B. (1988). First-mover advantages. Strategic Management Journal, 9(S1), 41-58.

Liebowitz, S. J., \& Margolis, S. E. (1994). Network externality: An uncommon tragedy. Journal of Economic Perspectives, 8(2), 133-150.

Liebowitz, S., \& Margolis, S. E. (2001). Network Effects and the Microsoft Case. Dynamic Competition and Public Policy: Technology, Innovation, and Antitrust Issues, Cambridge. 
Liebowitz, S. (2002). Rethinking the networked economy: The true forces driving the digital marketplace. AMACOM Div. American Management Association, Dallas.

Madsen, T. K., \& Servais, P. (1997). The internationalization of born globals: an evolutionary process?. International Business Review, 6(6), 561-583.

Makadok, R. (1998). Can first-mover and early-mover advantages be sustained in an industry with low barriers to entry/imitation?. Strategic Management Journal, 19(7), pp.683-696.

McDougall, P. P., Shane, S., \& Oviatt, B. M. (1994). Explaining the formation of international new ventures: The limits of theories from international business research. Journal of Business Venturing, 9(6), 469-487.

Nelson, R. R. 1991. Why do firms differ, and how does it matter?. Strategic Management Journal, 12(S2), 61-74.

Ohashi, H. (2003). The role of network effects in the US VCR market, 1978-1986. Journal of Economics \& Management Strategy, 12(4), 447-494.

Oviatt, B. M., \& McDougall, P. P. 1995. Global startups: Entrepreneurs on a worldwide stage. Academy of Management Perspectives, 9(2), 30-43.

Parker, G., Van Alstyne, M., \& Jiang, X. (2017). Platform Ecosystems: How Developers Invert the Firm. Management Information Systems Quarterly, 41(1), 255-266.

Peterson, M. F., Søndergaard, M., \& Kara, A. (2018). Traversing cultural boundaries in IB: The complex relationships between explicit country and implicit cultural group boundaries at multiple levels. Journal of International Business Studies, 49(8), 1081-1099.

Rennie, M. W. (1993). Born global. The McKinsey Quarterly, (4), 45-53.

Rietveld, J., \& Eggers, J. P. (2018). Demand heterogeneity in platform markets: Implications for complementors. Organization Science, 29(2), 304-322.

Rogers, E. M. (1995). Diffusion of Innovations. Free Press:New York.

Rugman, A. M., \& Verbeke, A. (2004). A perspective on regional and global strategies of multinational enterprises. Journal of International Business Studies, 35(1), 3-18.

Shapiro, C., \& Varian, H. R. (1998). Information rules: a strategic guide to the network economy. Harvard Business Press.

Shy, O. (2001). The Economics of Network Industries. Cambridge university press.

Suarez, F. F. (2005). Network effects revisited: the role of strong ties in technology selection. Academy of Management Journal, 48(4), 710-720.

Stallkamp, M., \& Schotter, A. P. (2019). Platforms without borders? The international strategies of digital platform firms. Global Strategy Journal.

Statcounter. (2020). Social media statistics. Retrieved from: https://gs.statcounter.com/social-media-stats

Teece, D. J. 1986. Profiting from technological innovation: Implications for integration, collaboration, licensing and public policy. Research Policy, 15(6), 285-305.

UNCTAD (2016). World Investment Report 2016. Available at: http://www.unctad.org

Vahlne, J. E., \& Johanson, J. (2017). From internationalization to evolution: The Uppsala model at 40 years. Journal of International Business Studies, 48(9), 1087-1102.

Van Hove, L. (2016a). Metcalfe's Law and Network Quality: An Extension of Zhang et al. Journal of Computer Science and Technology, 31(1), 117-123.

Van Hove, L. (2016b). Measuring the value of mobile telecommunications networks. 
NETNOMICS: Economic Research and Electronic Networking, 17(3), 191-222.

Zander, I., McDougall-Covin, P., \& Rose, E. L. (2015). Born globals and international business: Evolution of a field of research. Journal of International Business Studies, 46(1), 27-35.

Zhang, X. Z., Liu, J. J., \& Xu, Z. W. (2015). Tencent and Facebook data validate Metcalfe's law. Journal of Computer Science and Technology, 30(2), 246-251.

Zhu, F., \& Iansiti, M. (2012). Entry into platform-based markets. Strategic Management Journal, 33(1), 88-106.

Zhu, F., Li, X., Valavi, E., \& Iansiti, M. (2021). Network interconnectivity and entry into platform markets. Information Systems Research.

Zhou, T., \& Lu, Y. (2011). Examining mobile instant messaging user loyalty from the perspectives of network externalities and flow experience. Computers in Human Behavior, 27(2), 883-889 
Table 1: TABLE 1. List of Model Parameters

\begin{tabular}{|c|c|c|c|c|c|}
\hline Parameters & Remarks & $\begin{array}{c}\text { Figures } 1 \\
\text { and } 2\end{array}$ & $\begin{array}{c}\text { Figures } 3 \\
\text { and } 4\end{array}$ & $\begin{array}{l}\text { Figures } 5 \\
\text { and } 6\end{array}$ & Figure 7 \\
\hline$\alpha$ & The strength of direct network effects & 2 & $\begin{array}{l}\text { From } \\
0 \text { to } 3\end{array}$ & $\begin{array}{l}\text { From } \\
0 \text { to } 3\end{array}$ & $\begin{array}{l}\text { From } \\
0 \text { to } 3\end{array}$ \\
\hline$N_{A}$ & The total number of consumers in $\mathrm{A}$ & $100 \mathrm{~K}$ & $100 \mathrm{~K}$ & $100 \mathrm{~K}$ & $100 \mathrm{~K}$ \\
\hline$N_{B}$ & The total number of consumers in B & $100 \mathrm{~K}$ & $100 \mathrm{~K}$ & $100 \mathrm{~K}$ & $100 \mathrm{~K}$ \\
\hline$\gamma$ & $\begin{array}{l}\text { The importance of network effects } \\
\text { (scaling parameter) }\end{array}$ & 0.01 & 0.01 & 0.01 & 0.01 \\
\hline$\mu$ & Mean value of reluctance & 400 & 400 & 400 & 400 \\
\hline$\sigma$ & Standard deviation of reluctance & 300 & 300 & 300 & 300 \\
\hline$Q_{F}$ & Quality of the first mover's service & 0 & 0 & 0 & 0 \\
\hline$Q_{L}$ & Quality of the latecomer's service & $\begin{array}{l}0 \\
0\end{array}$ & $\begin{array}{l}0 \\
0\end{array}$ & $\begin{array}{c}\text { From } \\
0 \text { to } 200\end{array}$ & $\begin{array}{l}\text { From } \\
0 \text { to } 3000\end{array}$ \\
\hline$t_{F}$ & The first mover's entry timing & 0 & 0 & 0 & 0 \\
\hline$t_{L}$ & The latecomer's entry timing & 1 & 1 & 1 & 1 \\
\hline$t_{E}$ & Expansion timing & 3 & 3 & 3 & 3 \\
\hline
\end{tabular}


FIGURE 1. Typical Competition Dynamics When the Latecomer Pursues Late Domestic Entry $(\alpha=2)$

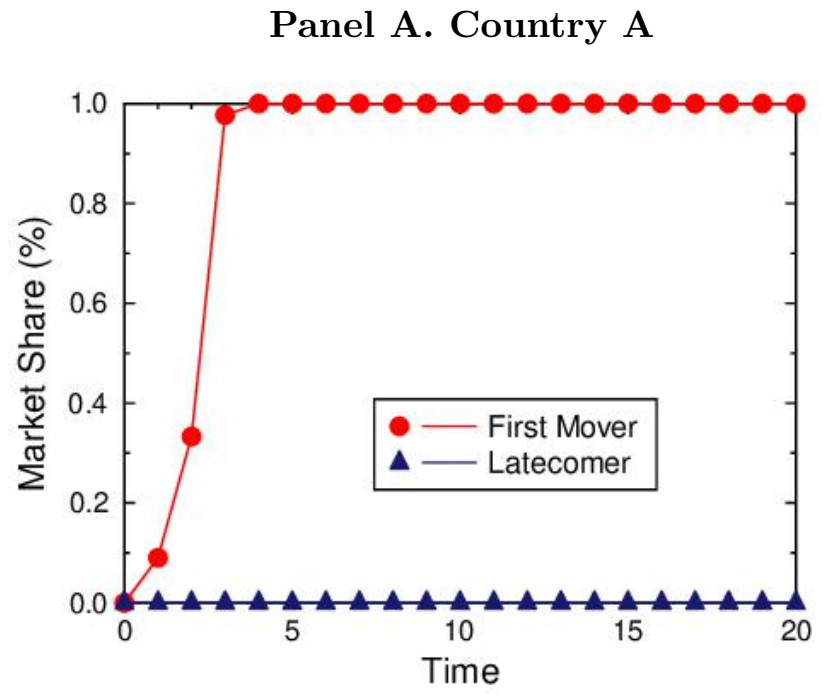

Panel B. Country B

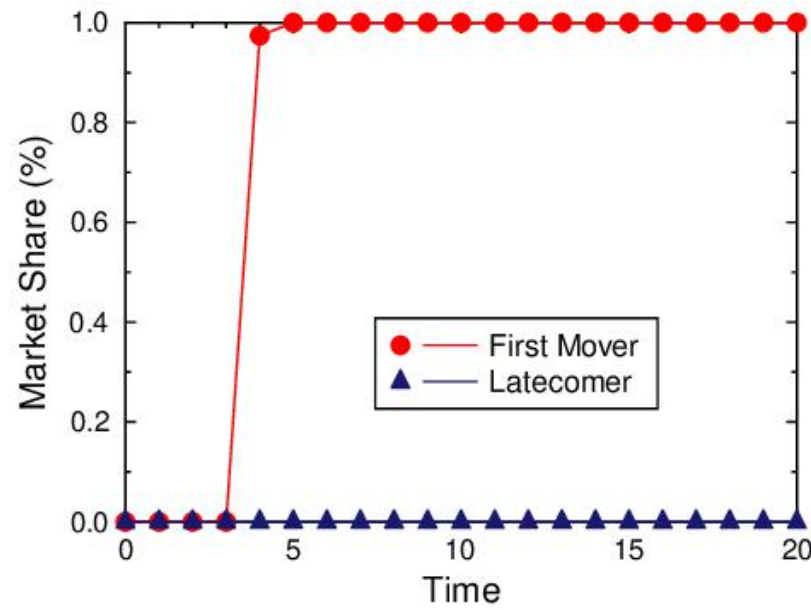

Panel C. Global Market Share

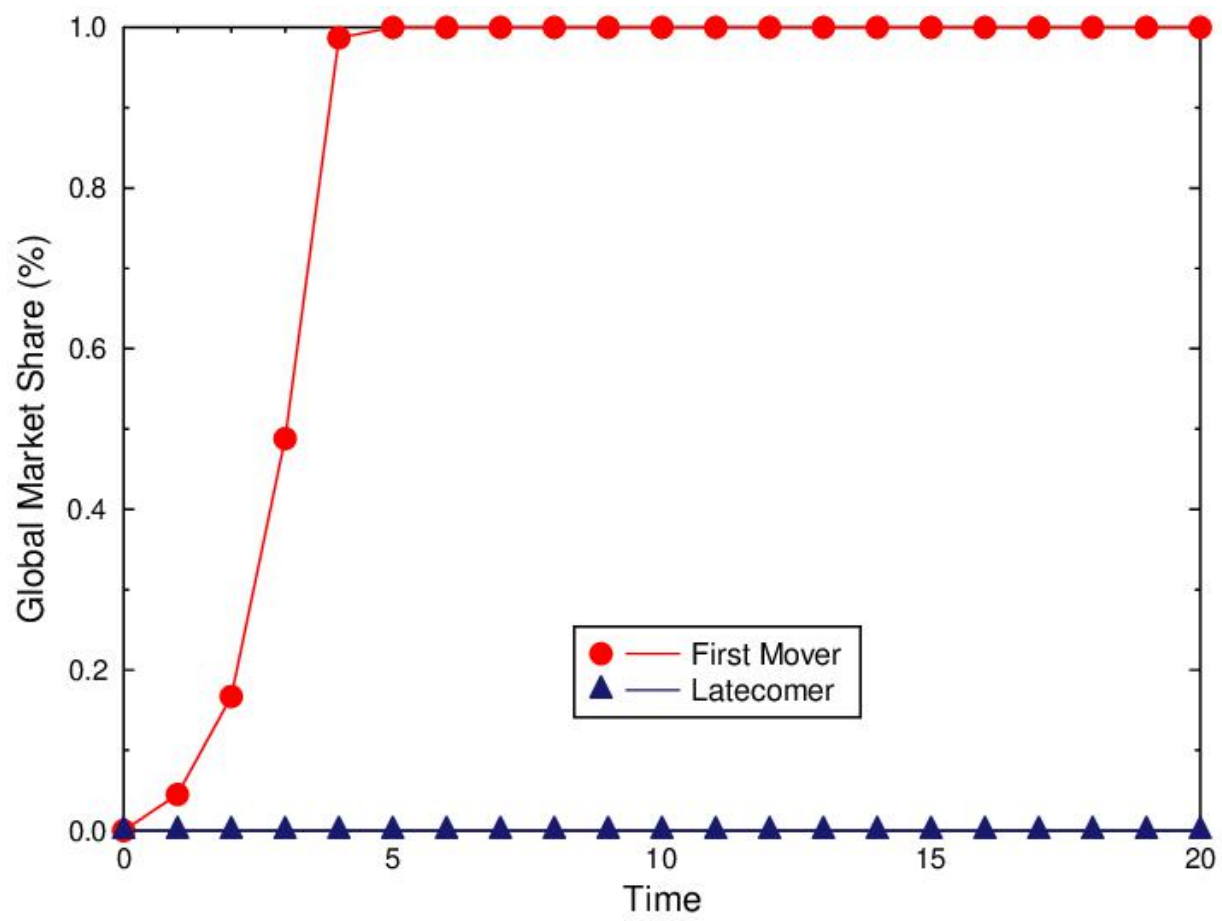

Note: Each country has 100,000 consumers. The first mover introduces its service in country $A$ at period 0 , and the latecomer enters country $A$ at period 1 . Both the first mover and latecomer internationalize their services after spending 2 periods in country $A$. 
FIGURE 2. Typical Competition Dynamics When the Latecomer Pursues Early Internationalization $(\alpha=2)$

Panel A. Country A

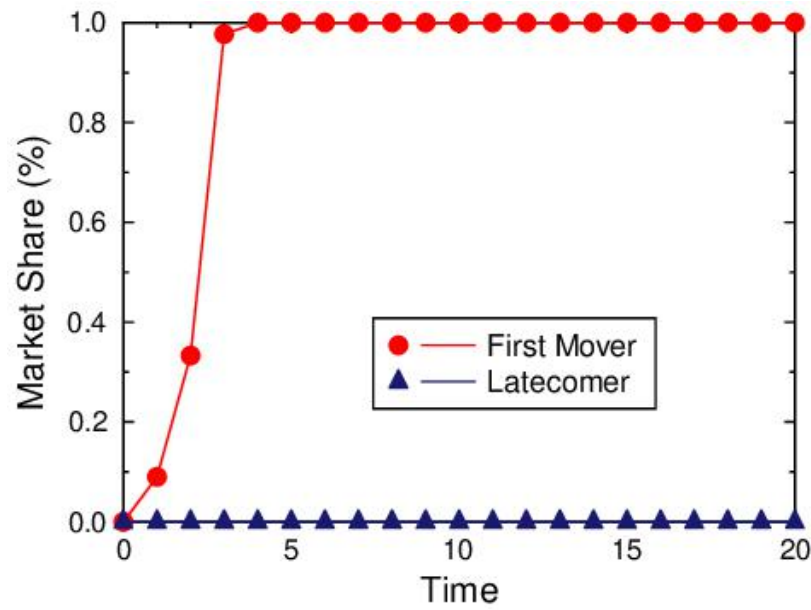

Panel B. Country B

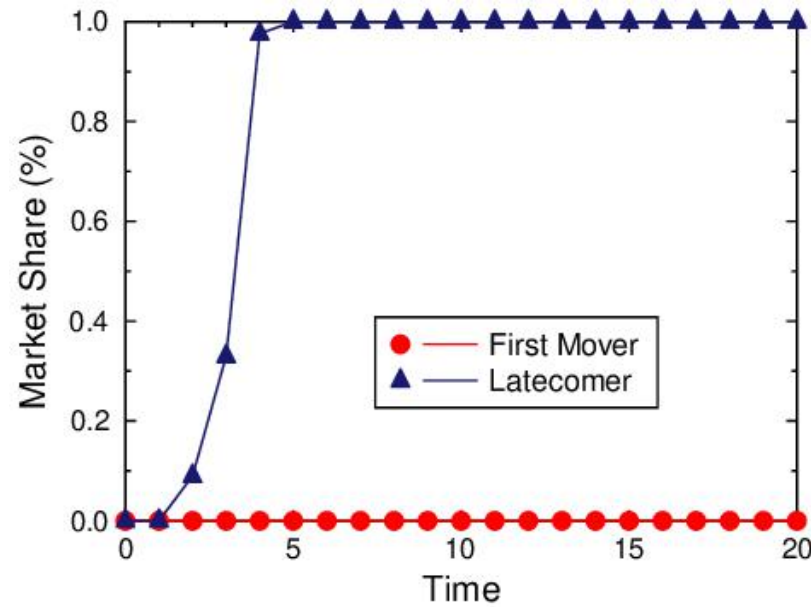

Panel C. Global Market Share

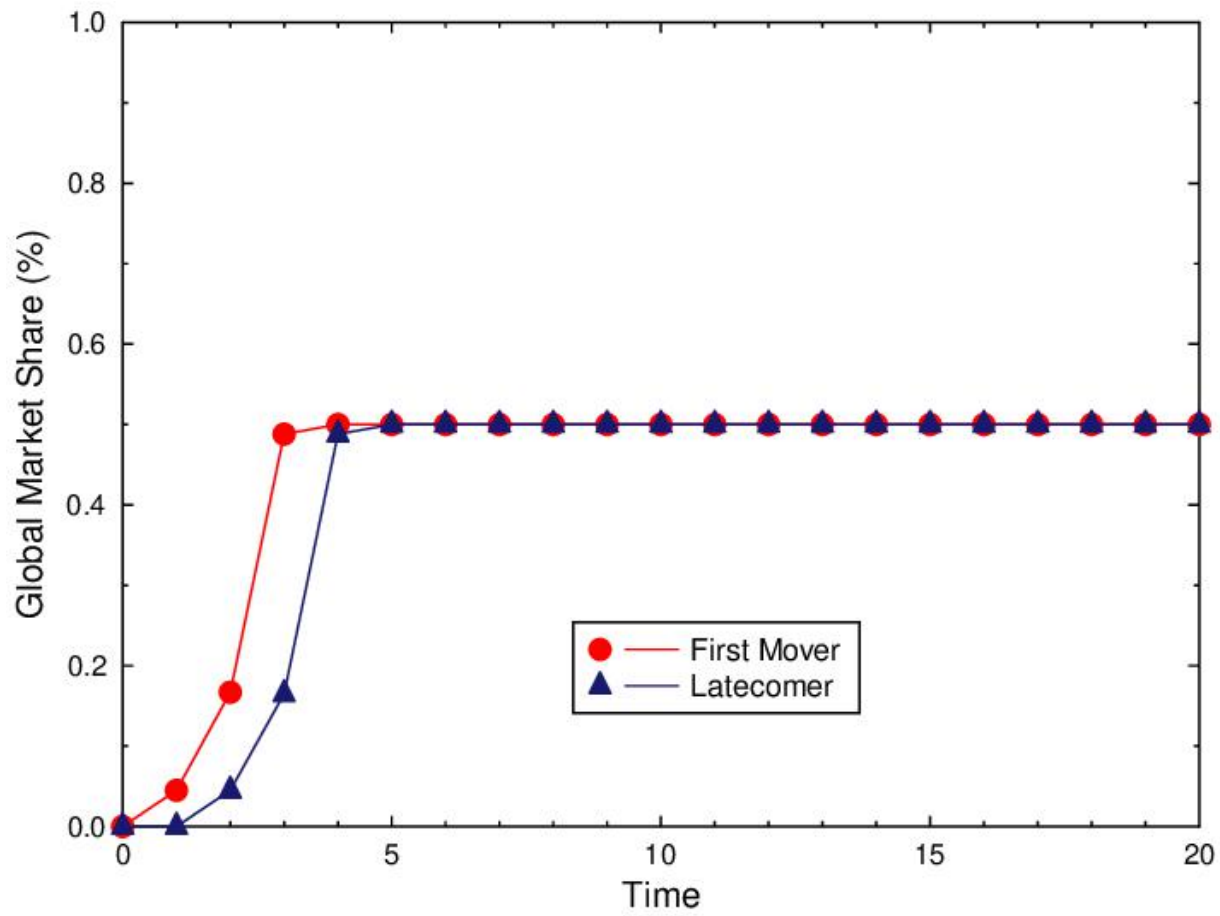

Note: Each country has 100,000 consumers. The first mover introduces its service in country $A$ at period 0 , and the latecomer enters country $B$ at period 1 . The first mover (latecomer) internationalizes its service after spending 2 periods in country $A$ (country $B$ ). 
FIGURE 3. Strength of Direct Network Effects and the Latecomer's Entry Strategy

Panel A. Global market share when the latecomer implements late domestic entry

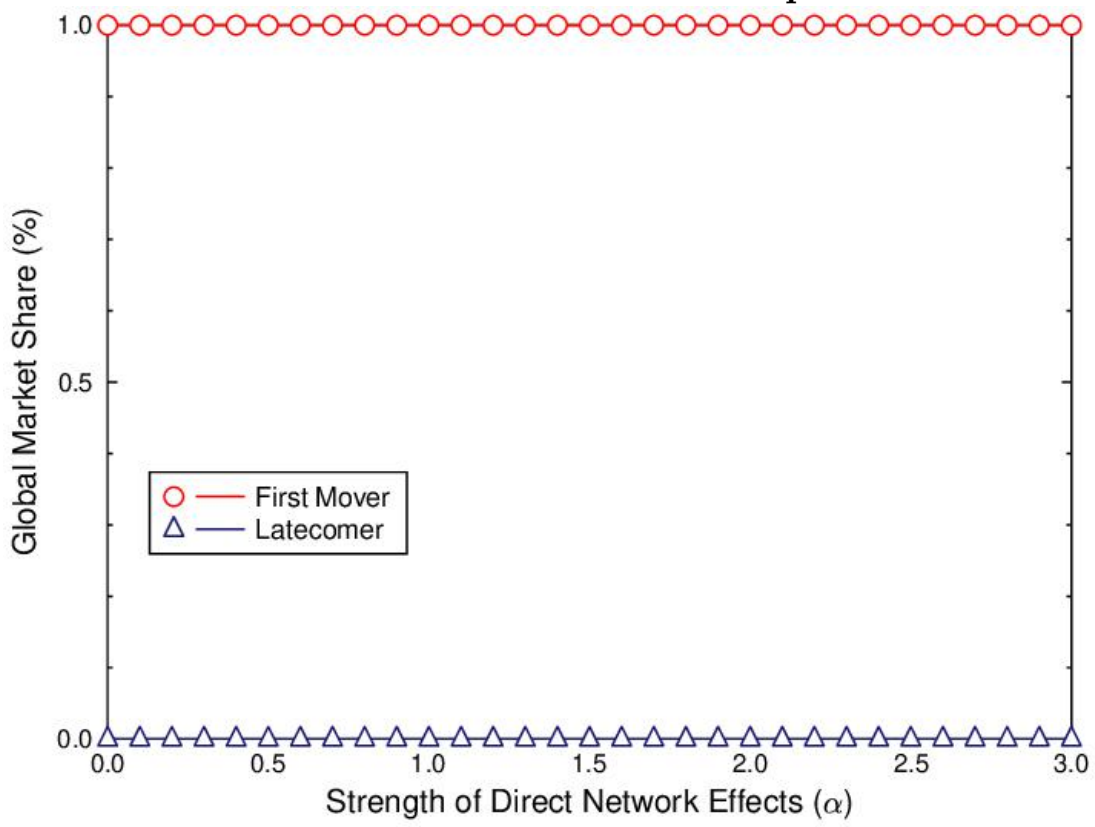

Panel B. Global market share when the latecomer implements early internationalization

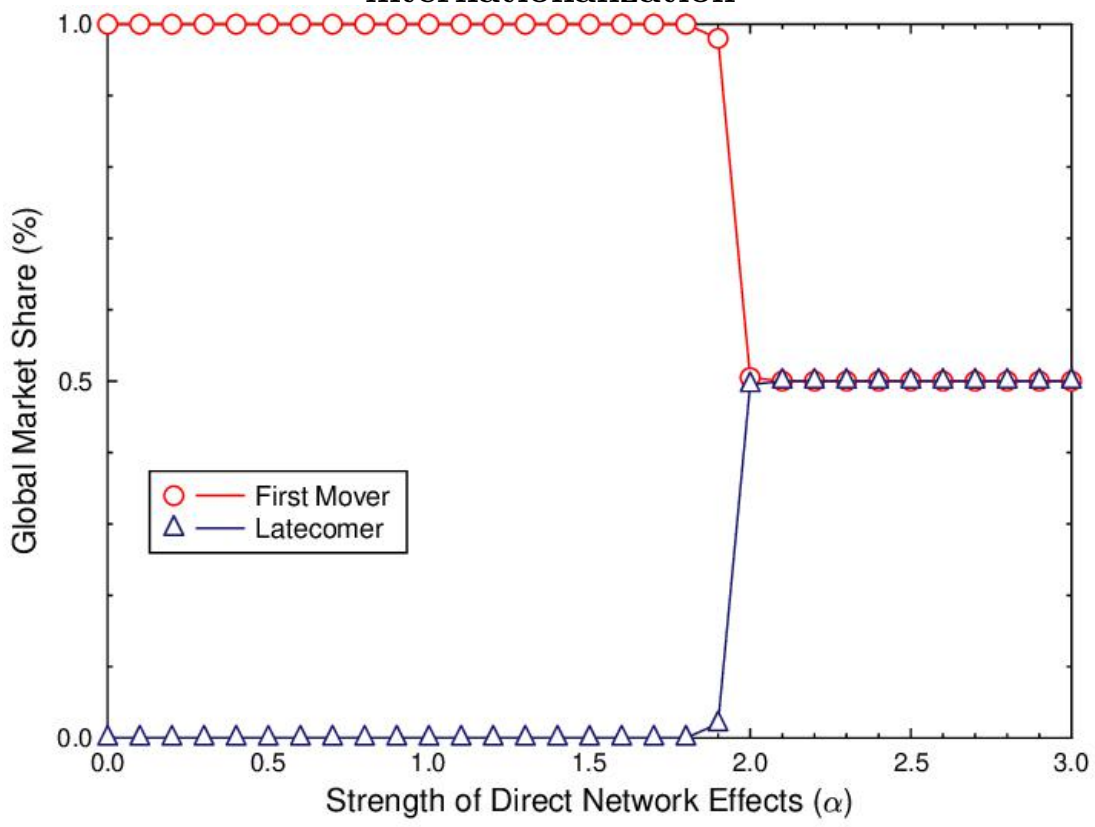

Note: In this figure, we compare the market share of the latecomer with respect to the strength of direct network effects $(\alpha)$. 
FIGURE 4. When the Latecomer Pursues Early Internationalization, Strong Direct Network Effects Buffer the First Mover's Indirect Network Effects

Panel A. Network effects of the first mover and latecomer in the foreign country

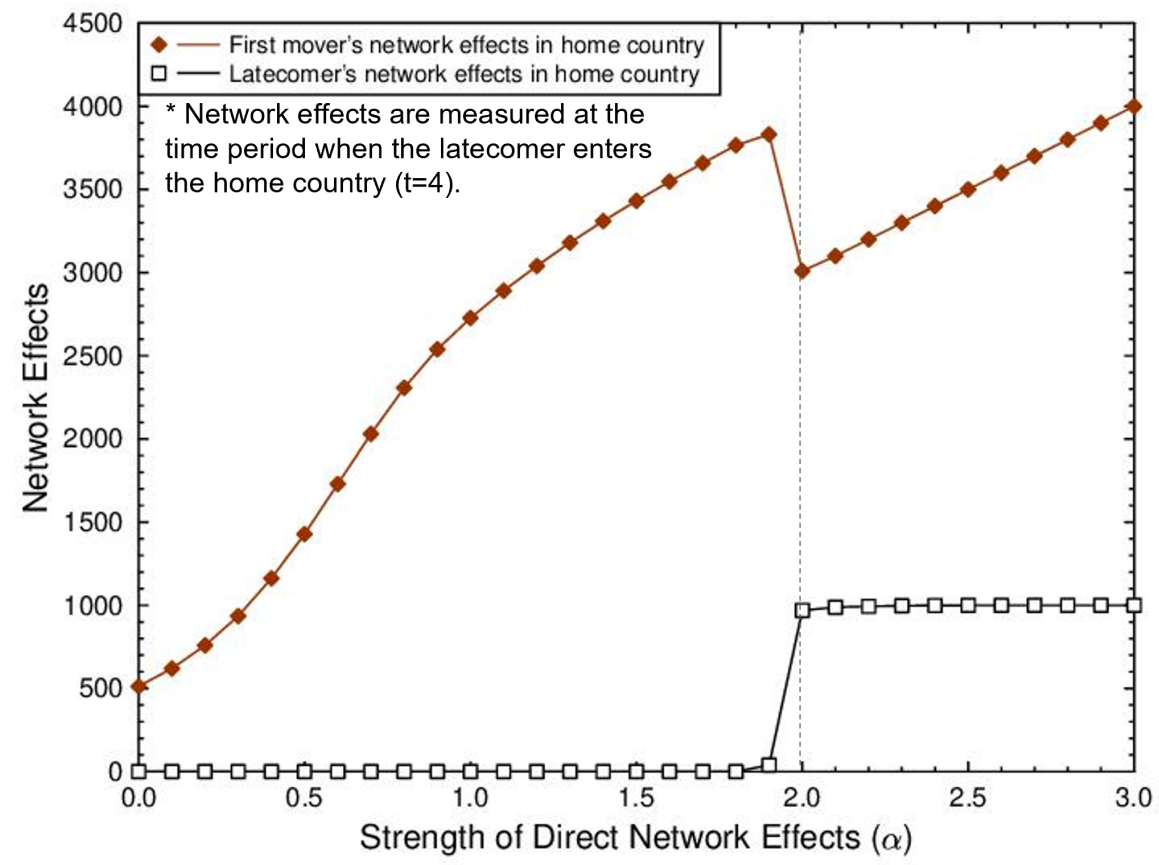

Panel B. Network effects of the first mover and latecomer in the home country

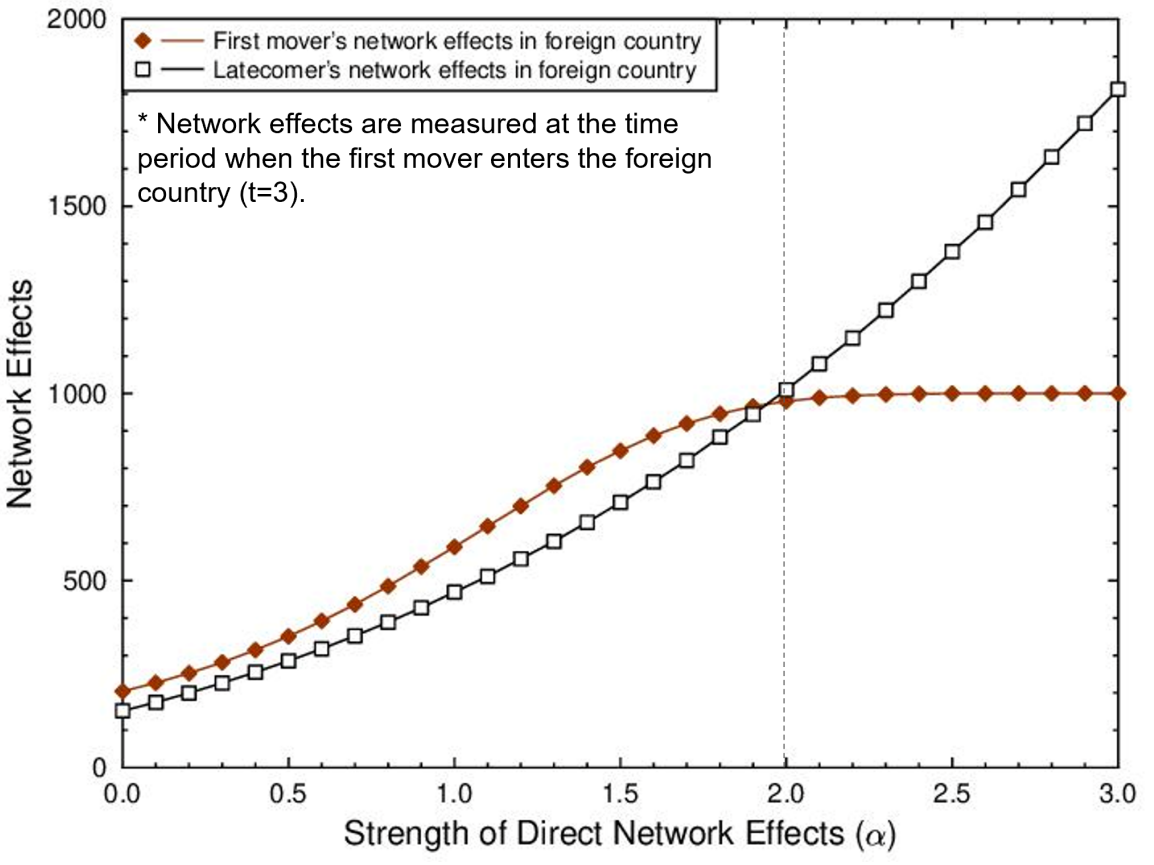


FIGURE 5. Competitive Outcome of the Latecomer's Entry Strategy

Panel A. Global market share of the latecomer with late domestic entry

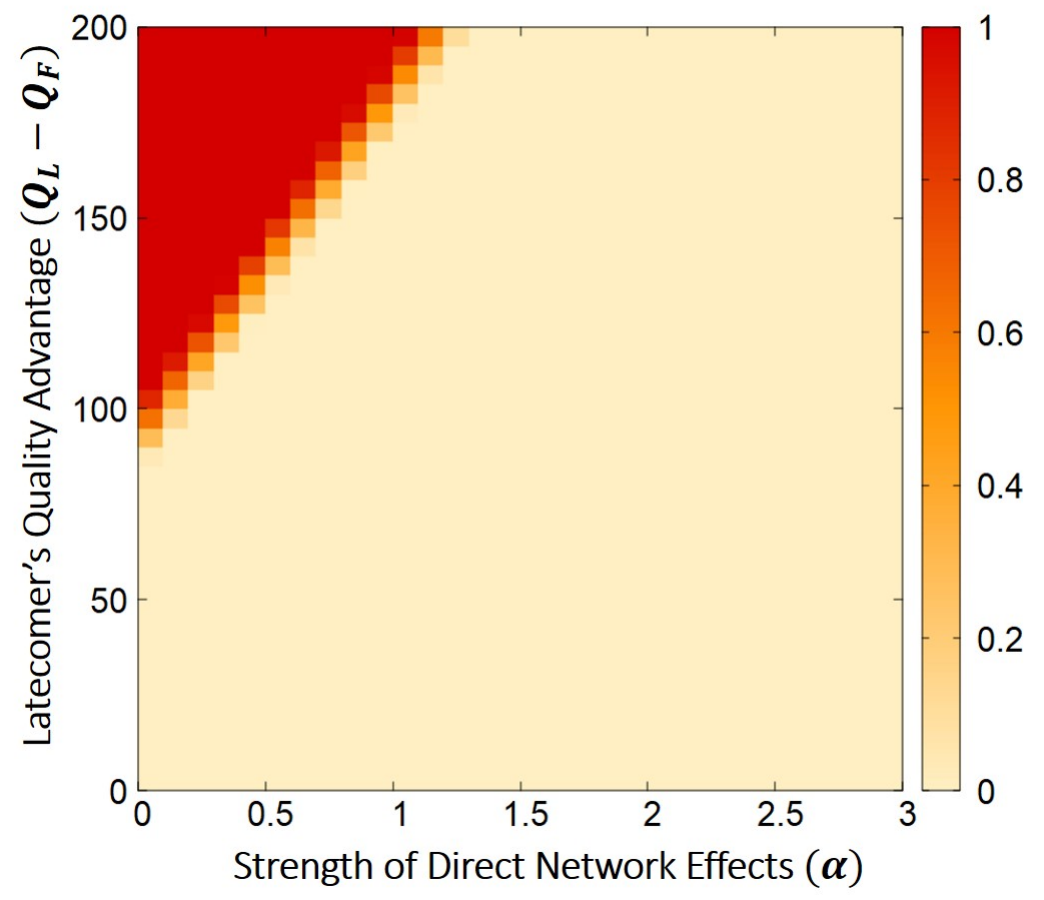

Panel B. Global market share of the latecomer with early internationalization

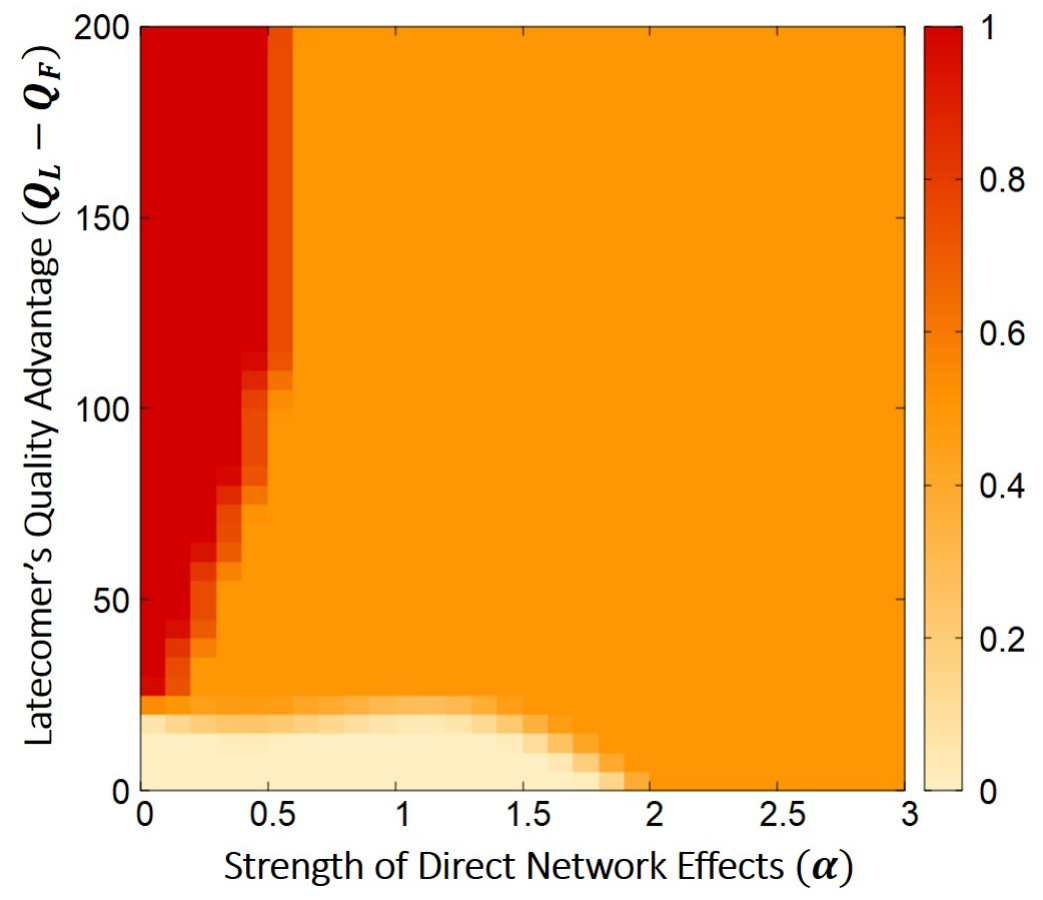




\section{FIGURE 6. The Optimal Strategy for the Latecomer}

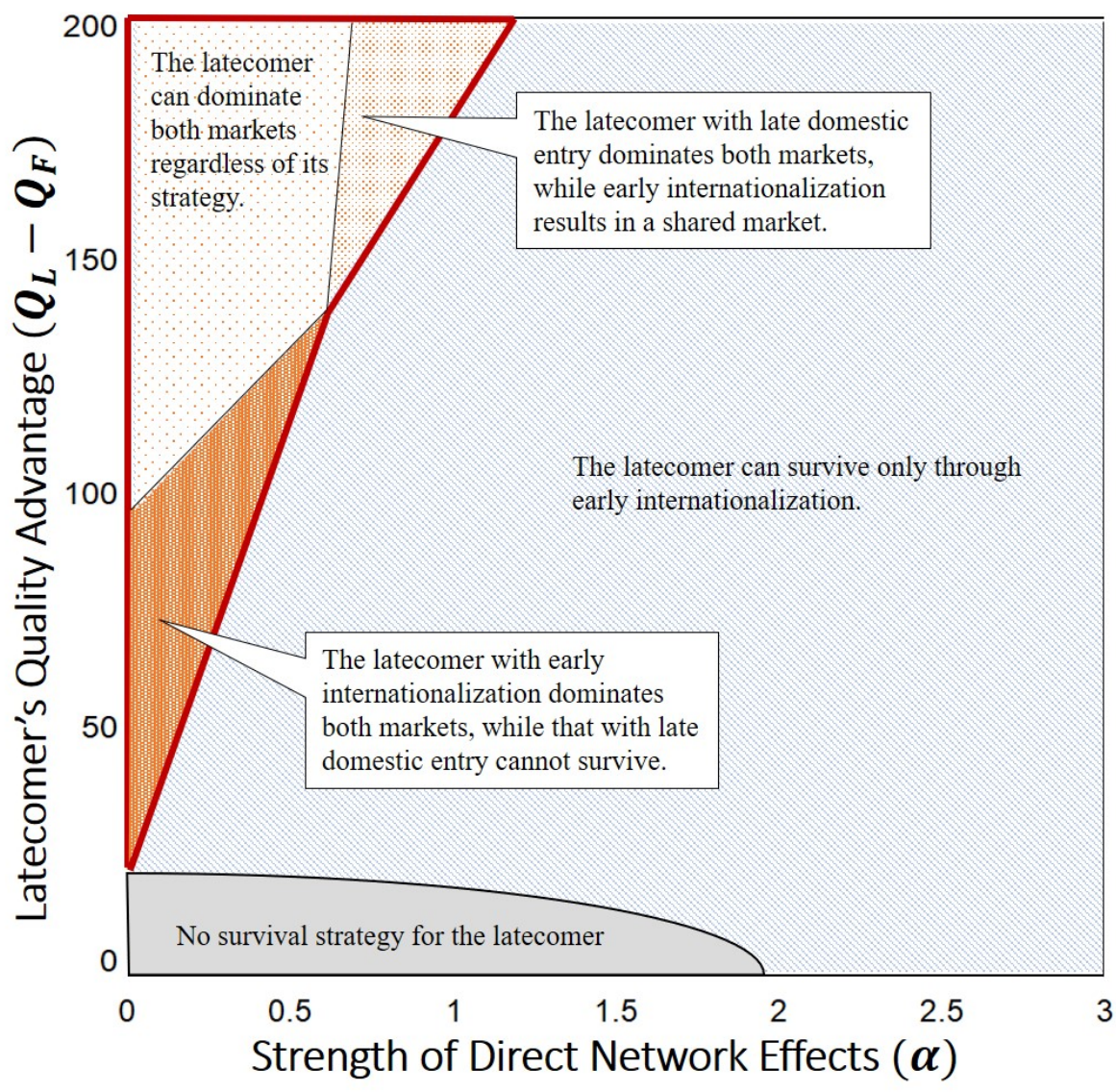

The latecomer can dominate both markets.

The latecomer can survive only in the foreign country.

The latecomer cannot survive. 
FIGURE 7. Quality Advantage Required for the Latecomer to Dominate Both Markets

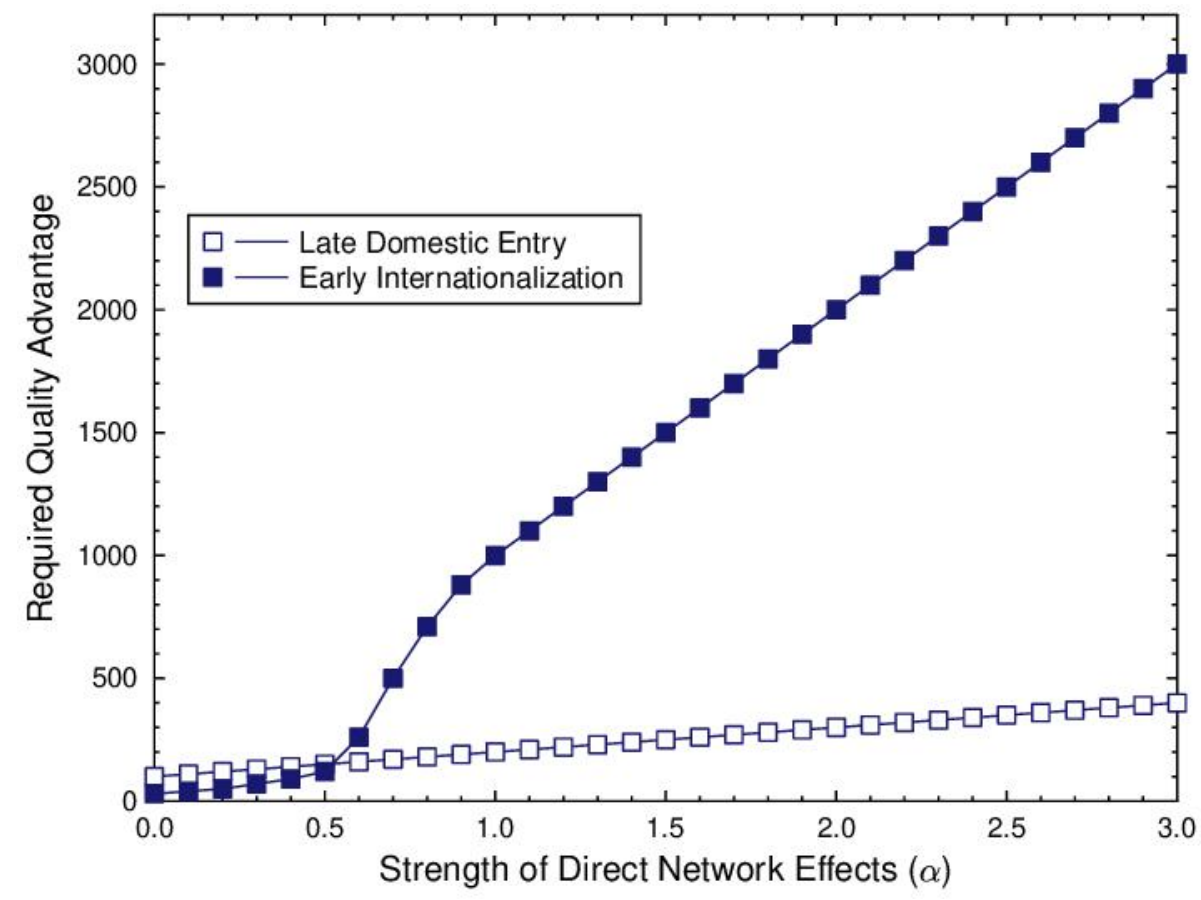




\section{APPENDIX A.Simulation Routines for Model}

Panel A. Firm strategy and market share

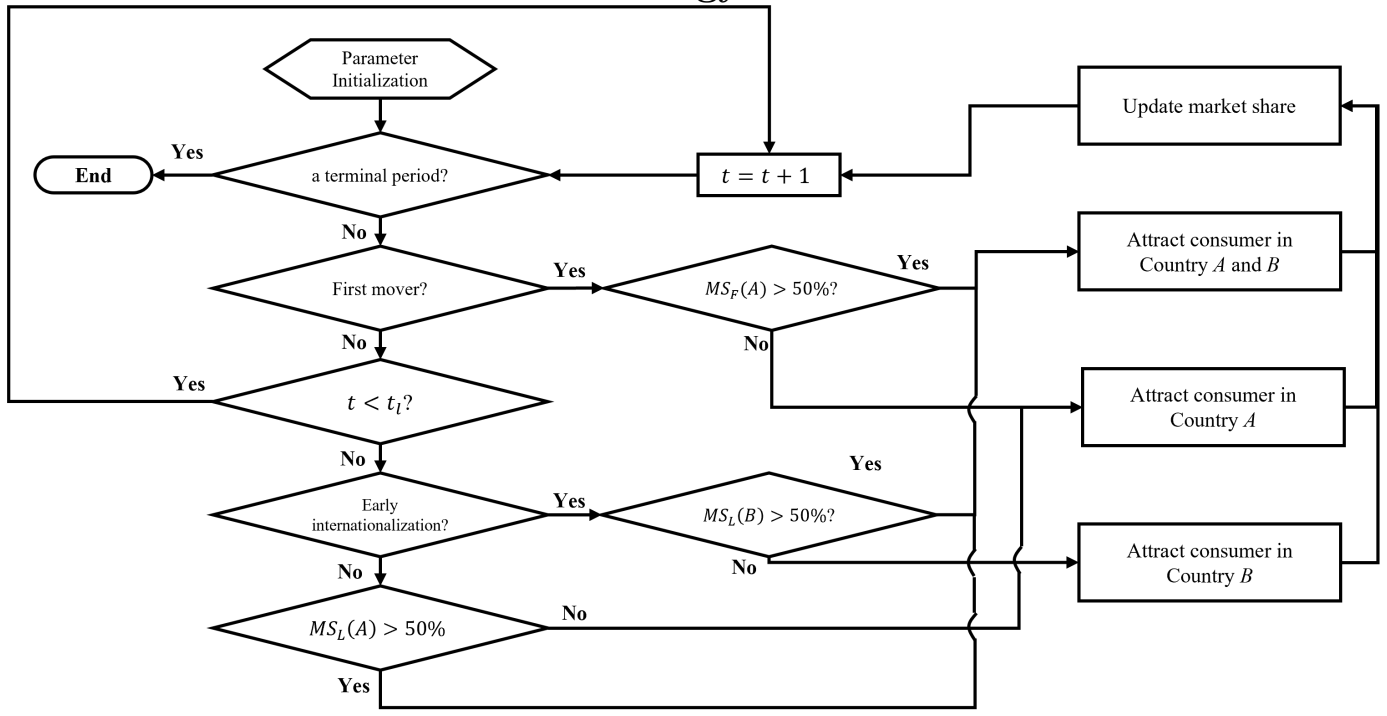

Panel B. Consumer adoption and switching rules

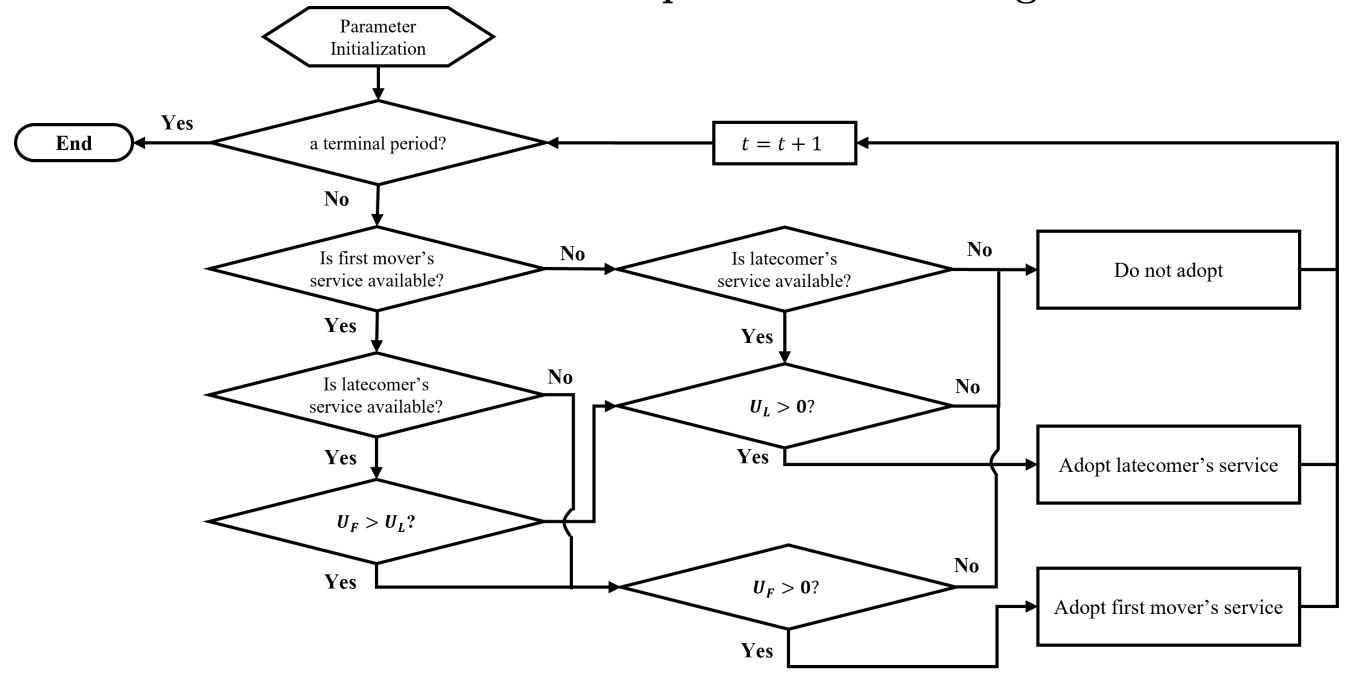


APPENDIX B.Probability that the First Mover Dominates Both Countries

Panel A. When the latecomer implements late domestic entry

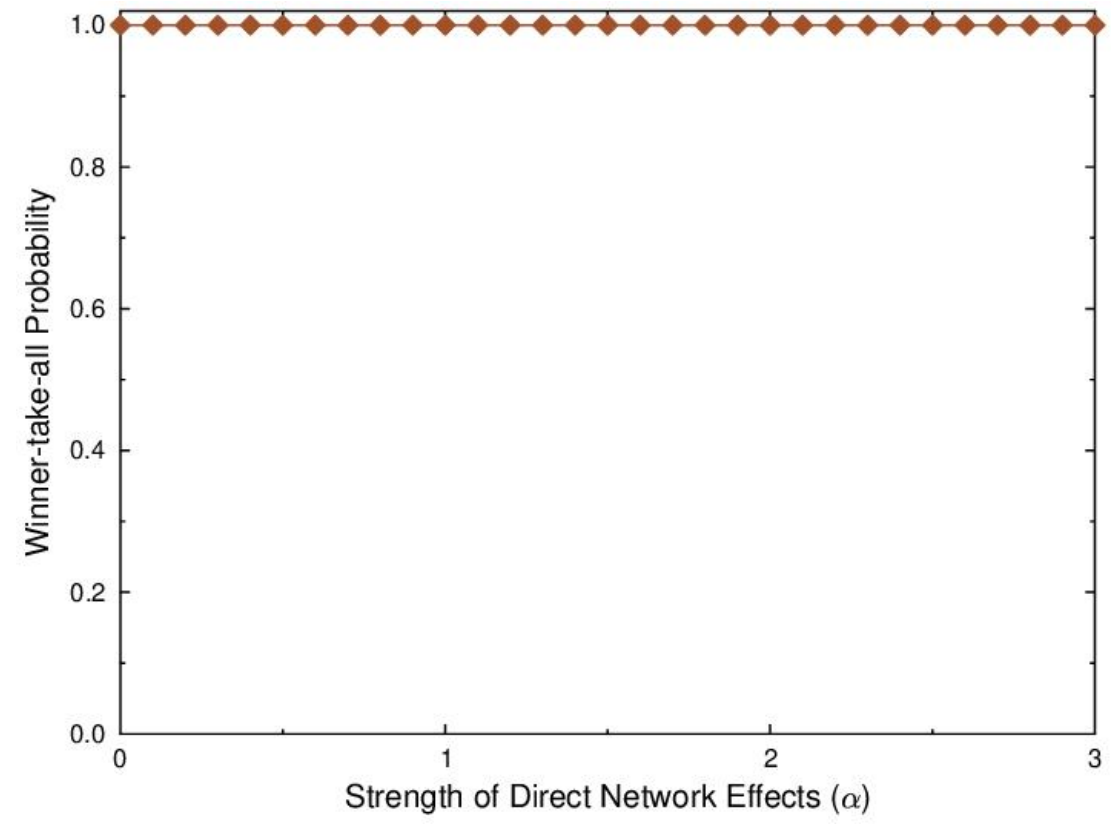

Panel B. When the latecomer implements early internationalization

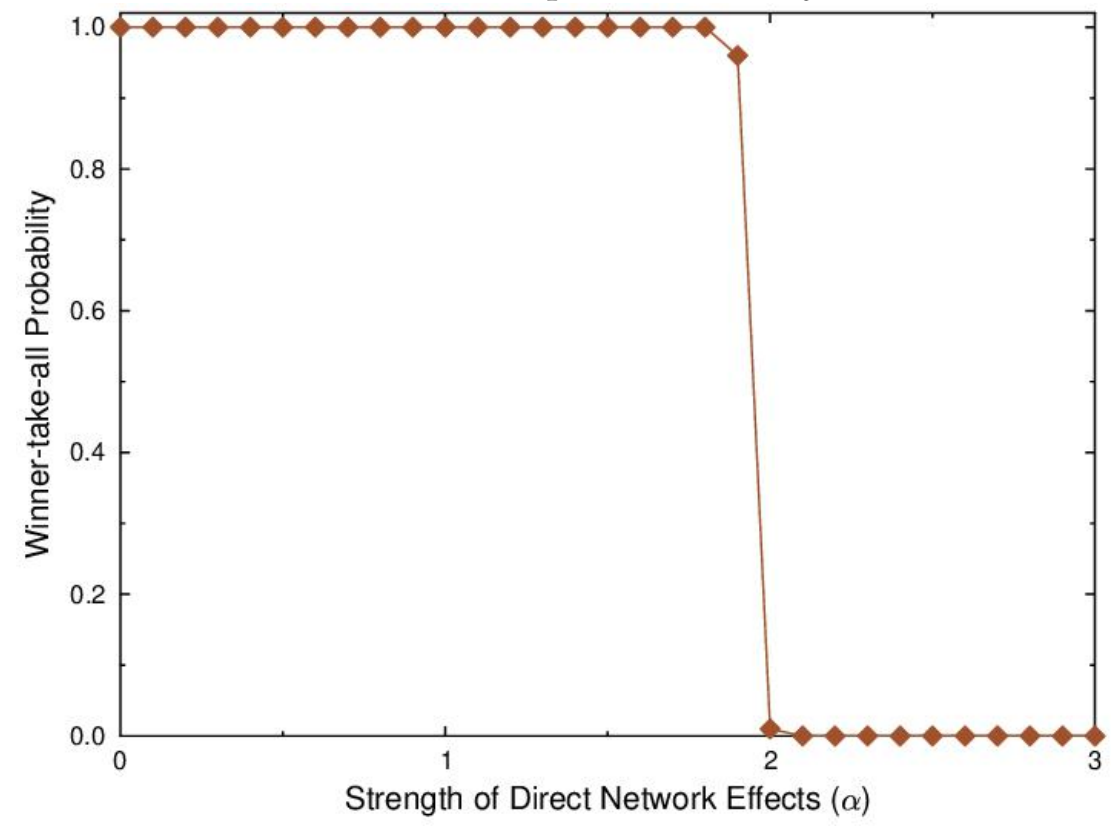




\section{APPENDIX C. Impact of Heterogeneity in Consumers' Inherent Preferences}

Panel A. When the home (foreign) country prefers the first mover's service (latecomer's service)

(i) Late Domestic Entry

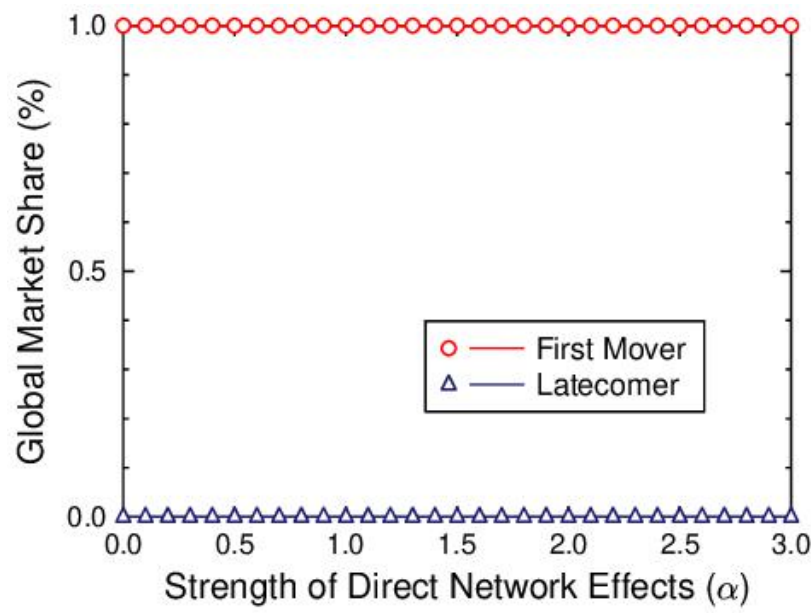

(ii) Early Internationalization

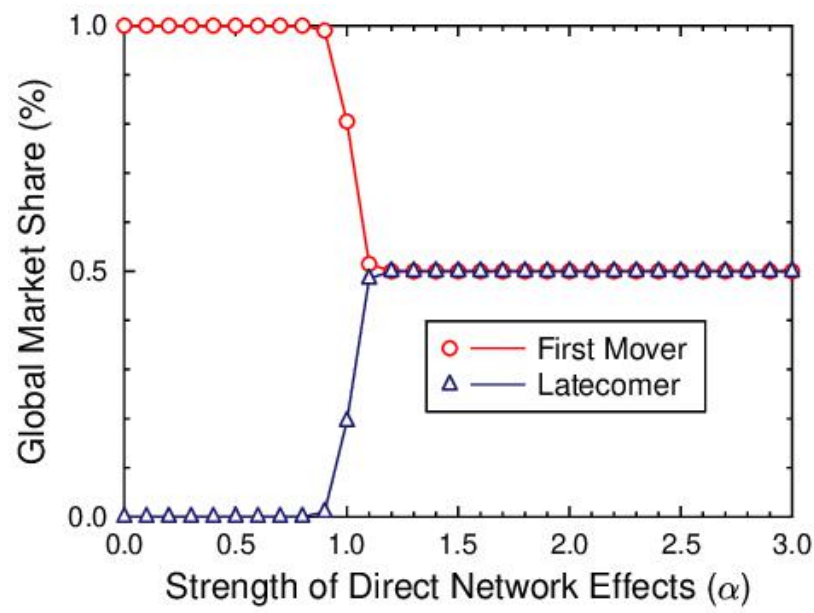

Panel B. When the home (foreign) country prefers the latecomer's service (first mover's service)

(i) Late Domestic Entry

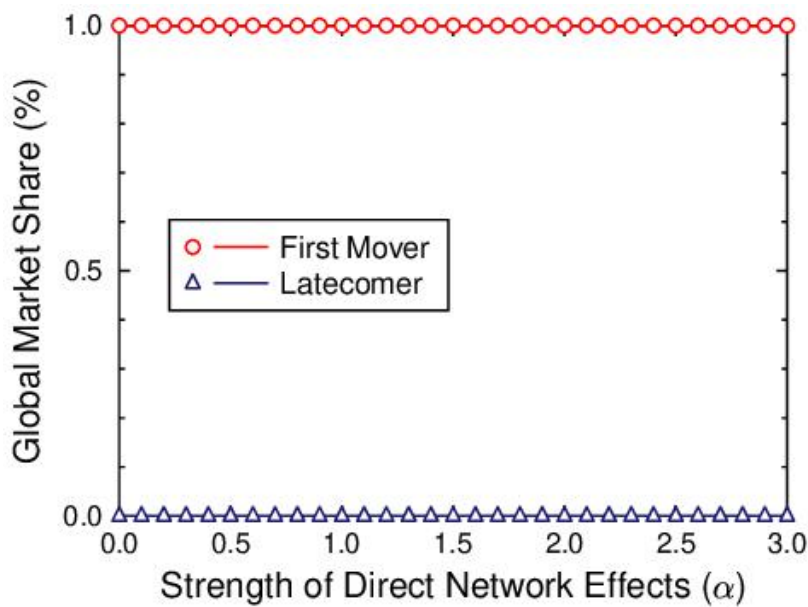

(ii) Early Internationalization

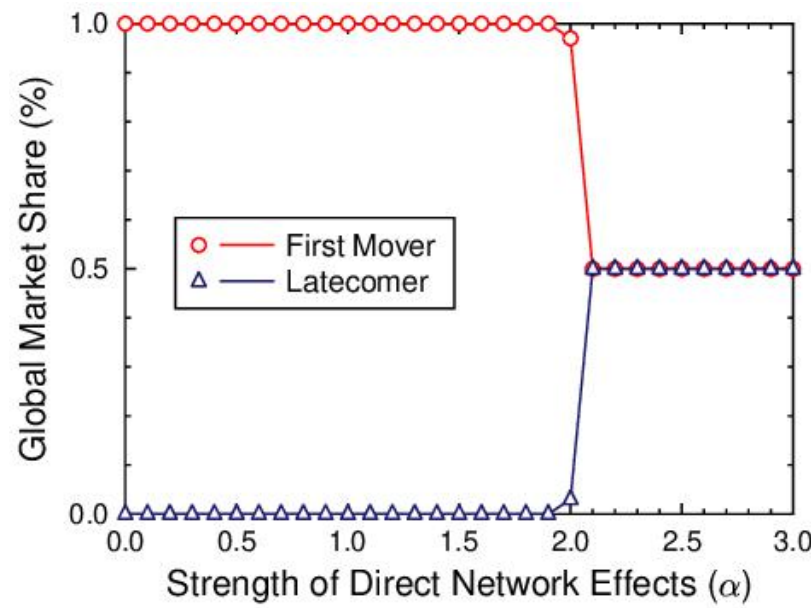

Note: We relax the assumption that reluctance (i.e., the inverse of inherent preference) is identical for a given consumer regardless of the digital service. In particular, we allow consumers in different countries to have different inherent preferences for the two services. In Panel A, country $A$ has $\mu_{F}=250$ and $\mu_{L}=300$, and country $B$ has $\mu_{F}=300$ and $m u_{L}=250$. In Panel B, country $A$ has $\mu_{F}=300$ and $\mu_{L}=250$, and country $B$ has $\mu_{F}=250$ and $\mu_{L}=300$. 


\section{APPENDIX D. Impact of Heterogeneity in Market Sizes}

Panel A. When the home country is greater than the foreign country $\left(N_{A}=105 K\right.$;

$$
\left.N_{B}=100 K\right)
$$

(i) Late Domestic Entry

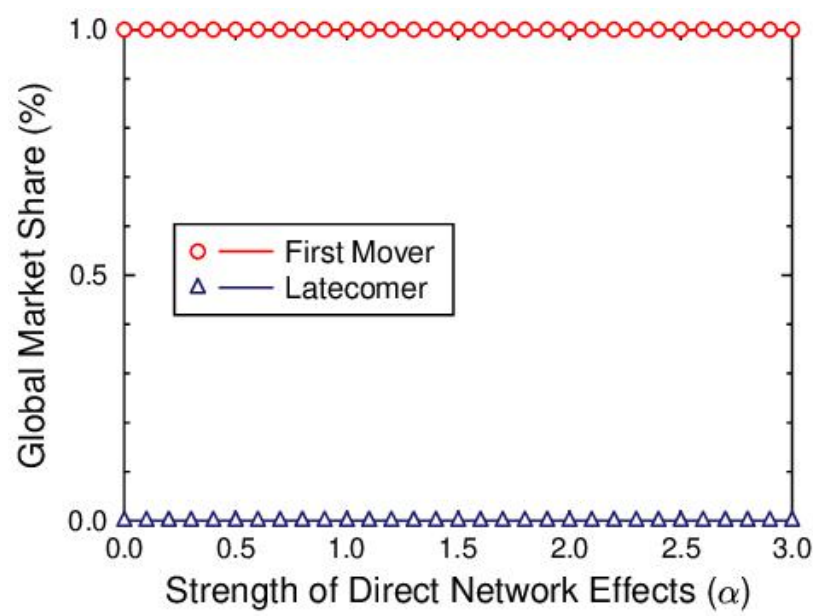

(ii) Early Internationalization

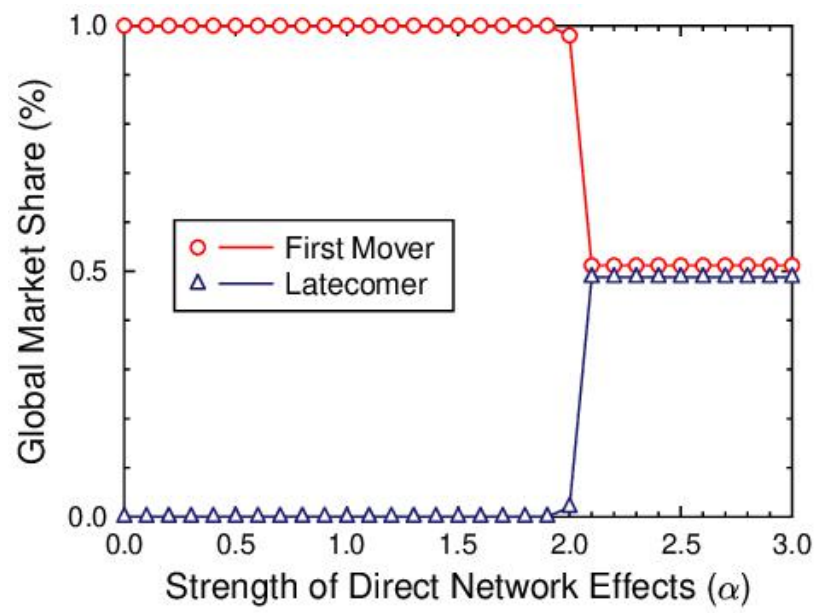

Note: When the home country has more consumers, the first mover enjoys greater indirect network effects. Thus, the survival regime for the latecomer with early internationalization shrinks.

Panel B. When the home country is smaller than the foreign country $\left(N_{A}=100 K\right.$;

$$
\left.N_{B}=105 K\right)
$$

(i) Late Domestic Entry

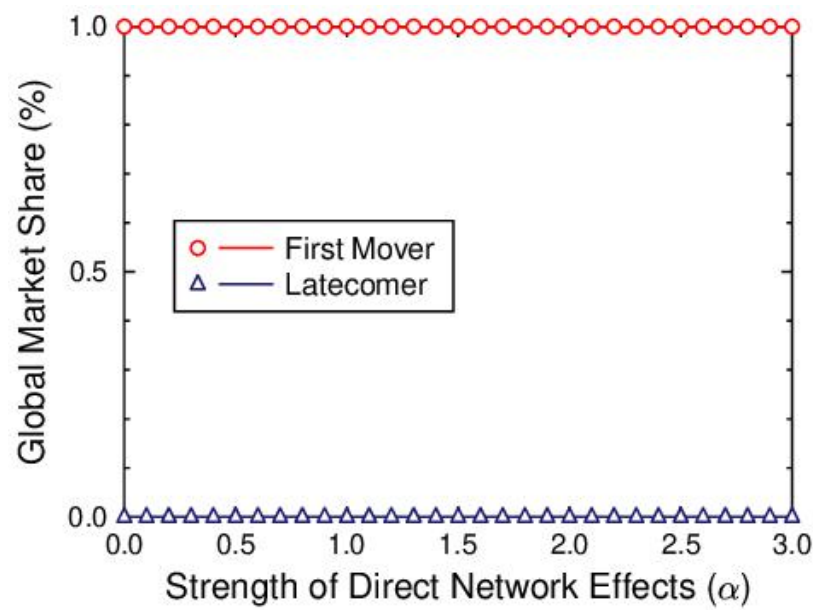

(ii) Early Internationalization

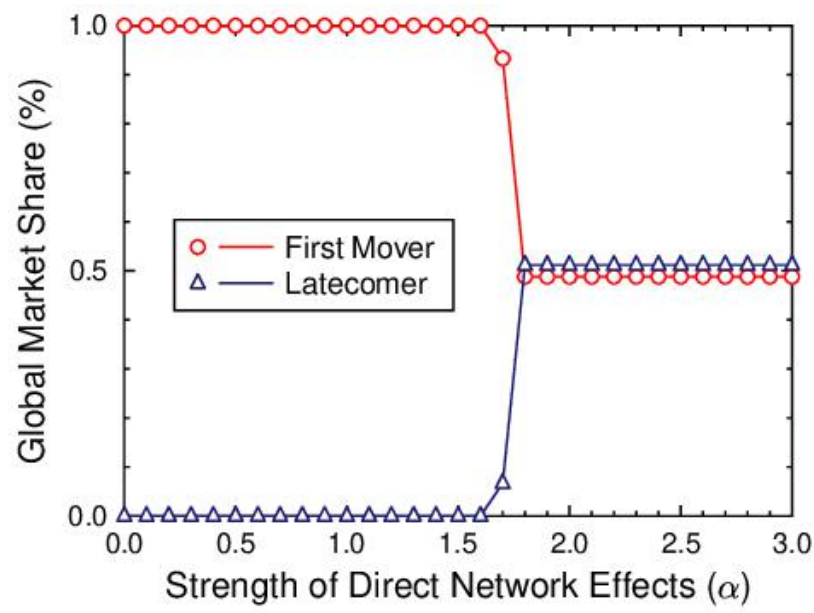

Note: When the foreign country has more consumers, the latecomer enjoys greater direct network effects. Thus, the survival regime for the latecomer with early internationalization expands. 


\section{APPENDIX E. Different Specifications of Network Effects Panel A. A logarithmic function}

(i) Late Domestic Entry

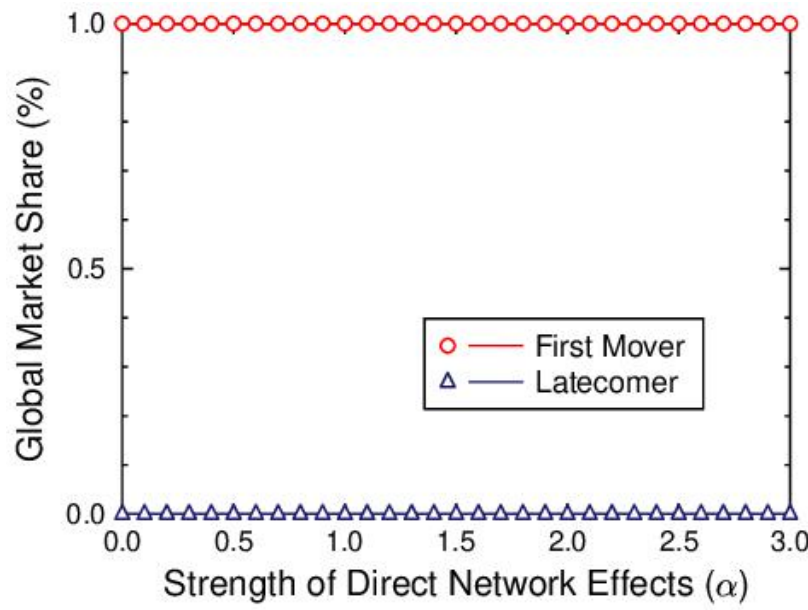

(ii) Early Internationalization

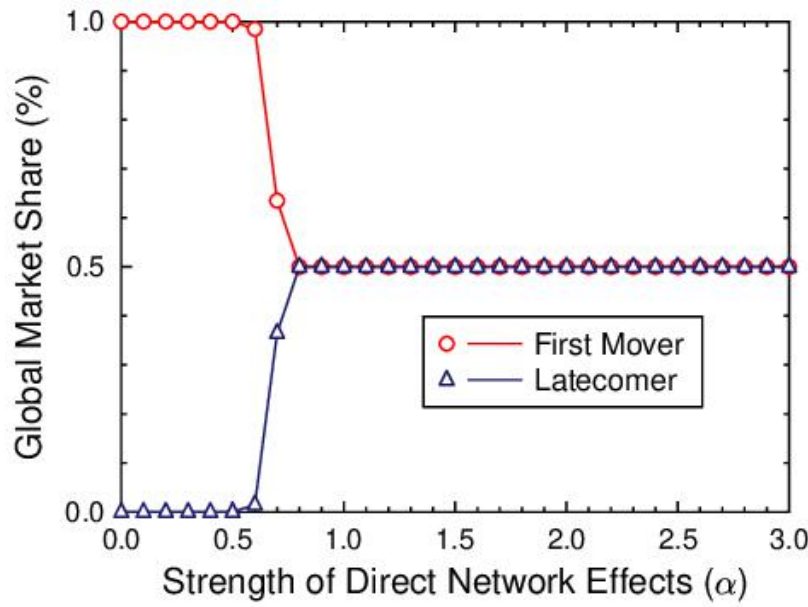

Note: We assume that the network effects of service $j$ in country $A$ are given by $\omega_{A j t}=\log \left(\alpha n_{A j(t-1)}+\right.$ $\left.n_{A j(t-1)}+n_{B j(t-1)}+1\right)$. The set of parameters used for this analysis is as follows: $\mu=3 ; \sigma=1 ;$ gamma $=0.5$. Having 1 in a $\log$ function prevents the case of $\log (0)$.

Panel B. Controlling the size of network effects

(i) Late Domestic Entry

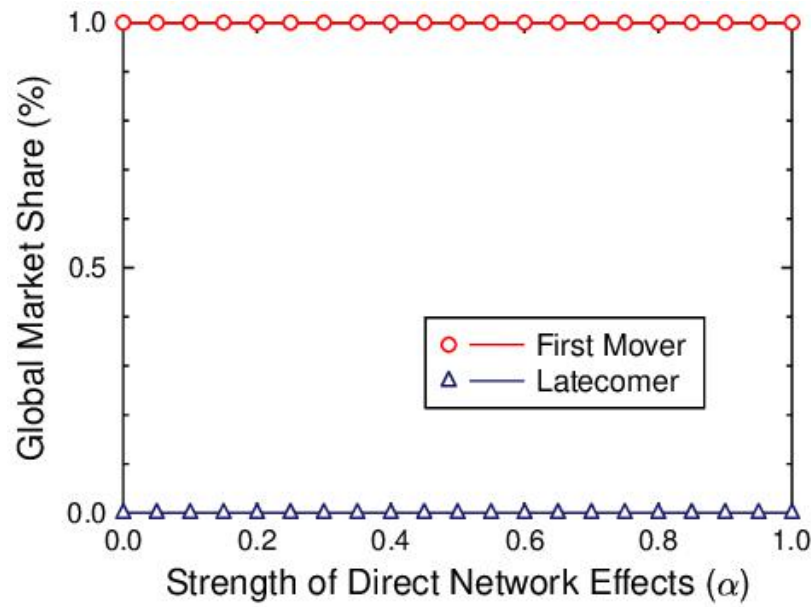

(ii) Early Internationalization

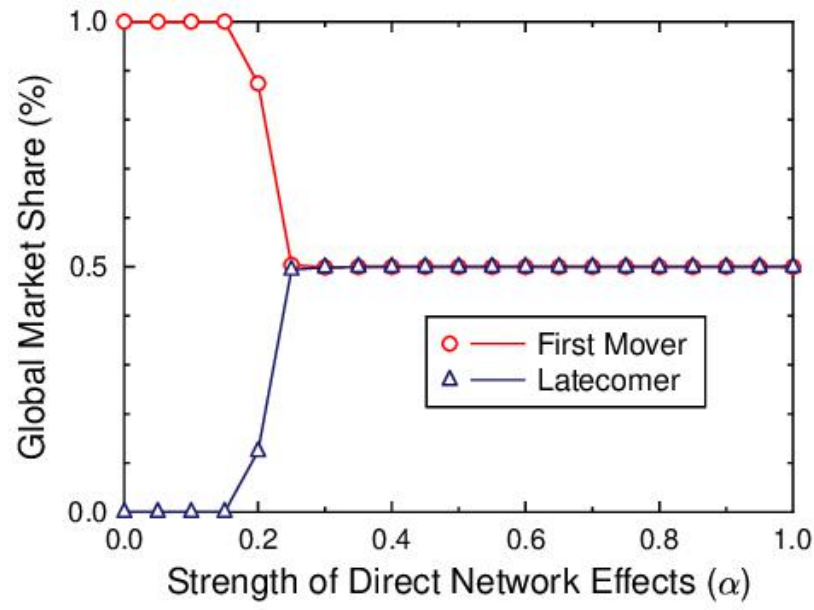

Note: We assume that the network effects of service $j$ in country $A$ are given by $\omega_{A j t}=\alpha n_{A j(t-1)}+(1-$ $\alpha)\left(n_{A j(t-1)}+n_{B j(t-1)}\right) / 2$, where $0 \leq \alpha \leq 1$. The set of parameters used for this analysis is as follows: $\mu=400 ; \sigma=300 ; \gamma=0.02$. 


\section{APPENDIX F. Different Parameters for the Timing of Entry and Internationalization}

Panel A. $t_{F}=0 ; t_{L}=1 ; t_{E}=4$

(i) Late Domestic Entry

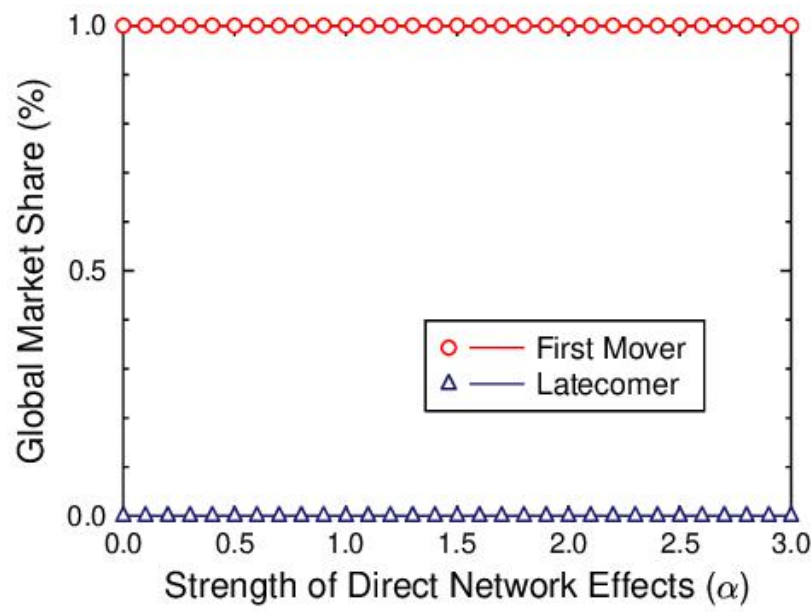

(ii) Early Internationalization

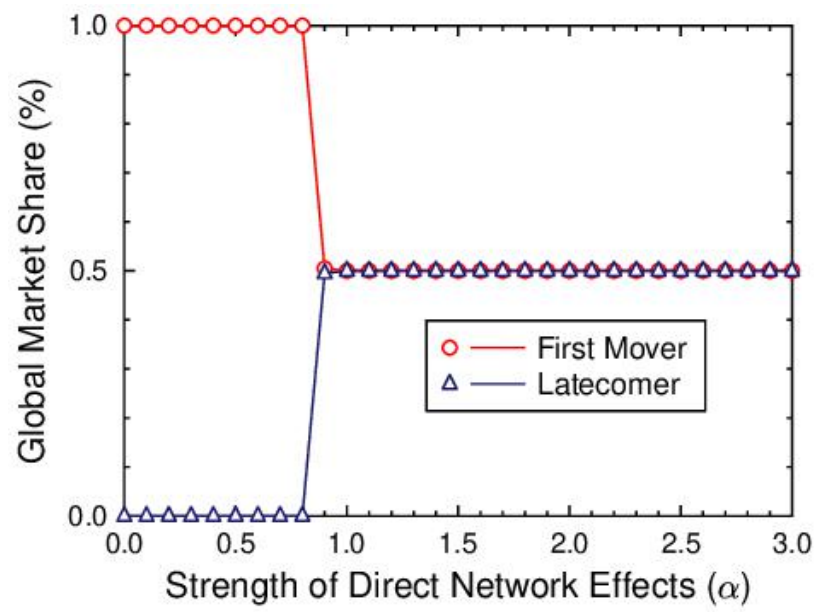

Note: When the first mover internationalizes its service later, the latecomer has more time to attract users in the foreign country before the first mover's entry. Thus, the survival regime for the latecomer with early internationalization expands.

Panel B. $t_{F}=0 ; t_{L}=2 ; t_{E}=4$

(i) Late Domestic Entry

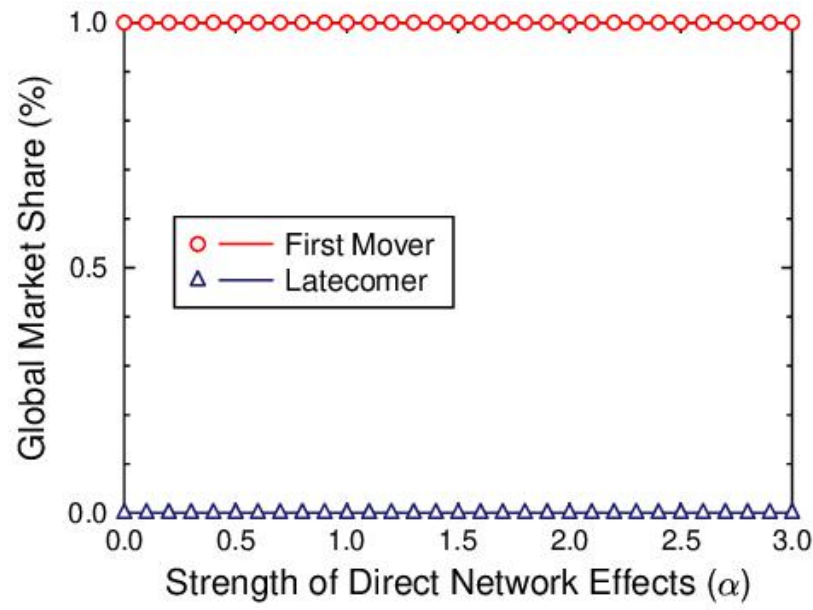

(ii) Early Internationalization

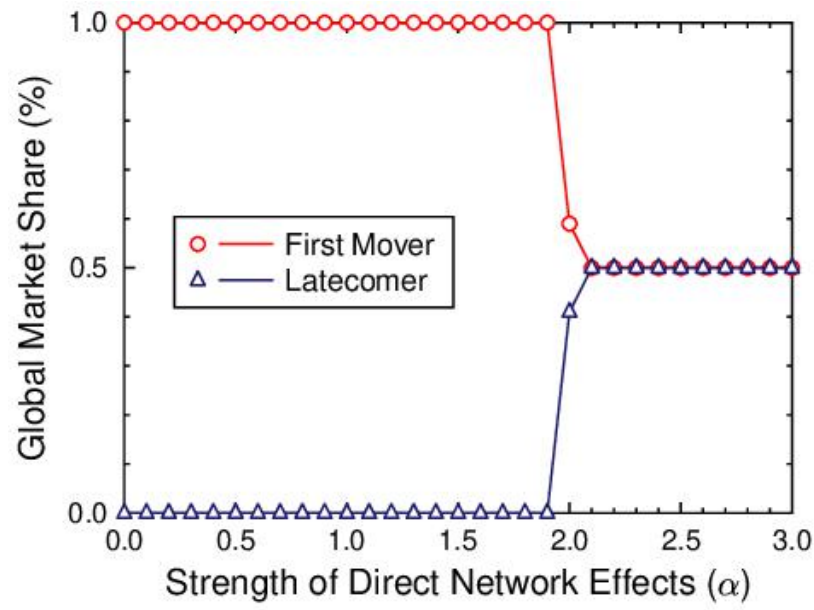

Note: When the latecomer enters the market in the later stage, the latecomer has less time to attract users in the foreign country before the first mover's entry. Thus, the survival regime for the latecomer with early internationalization shrinks. 
APPENDIX G. Different Parameters for the Reluctance Distribution

Panel A. Consumers are less reluctant to adopt a service $(\mu=380 ; \sigma=300)$

(i) Late Domestic Entry

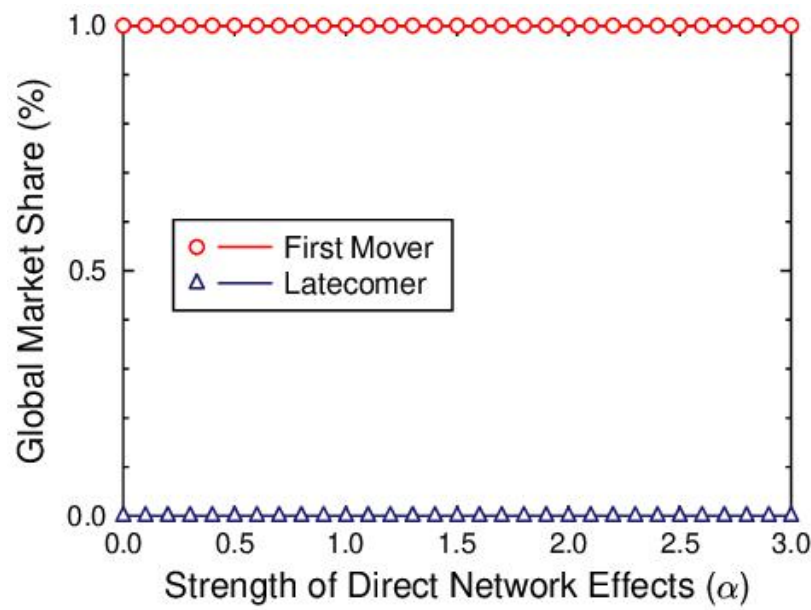

(ii) Early Internationalization

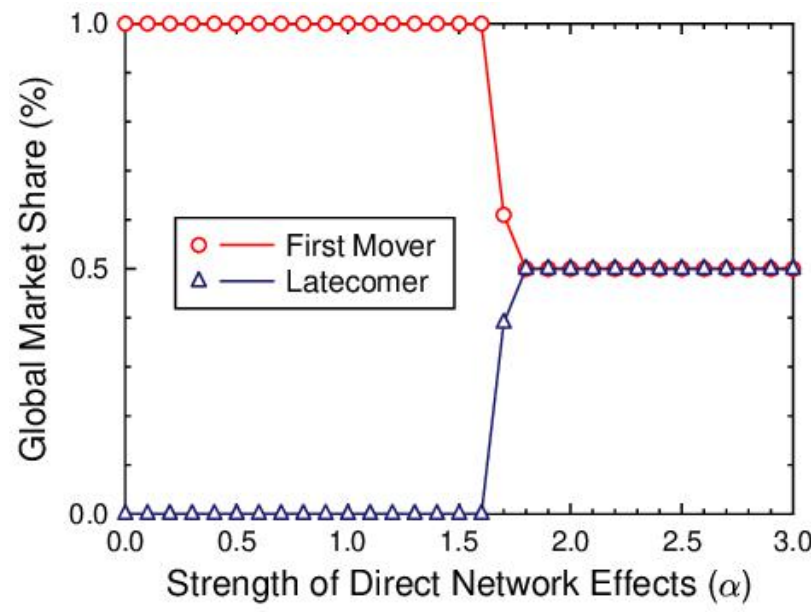

Note: When consumers are less reluctant to adopt a new digital service, the latecomer takes less time to attract users in the foreign country. Thus, the survival regime for the latecomer with early internationalization expands.

Panel B. Consumers are more reluctant to adopt a service $(\mu=420 ; \sigma=300)$

(i) Late Domestic Entry

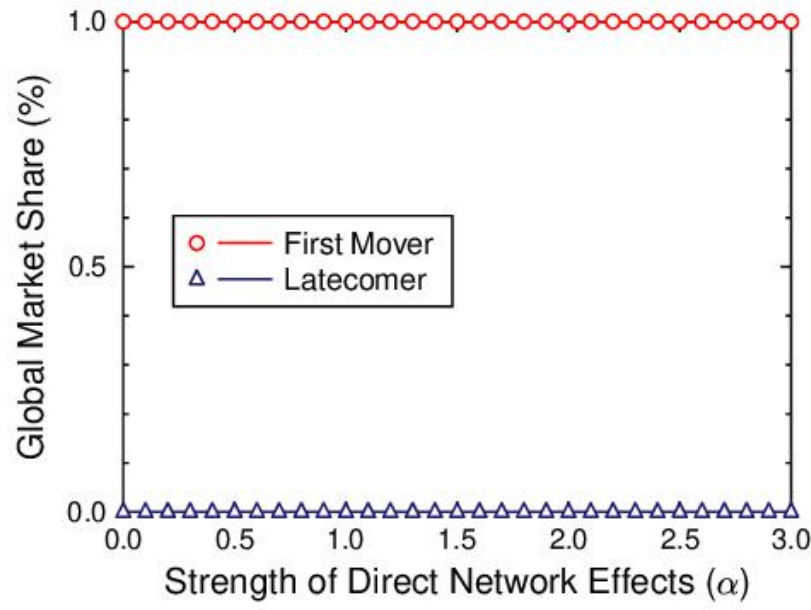

(ii) Early Internationalization

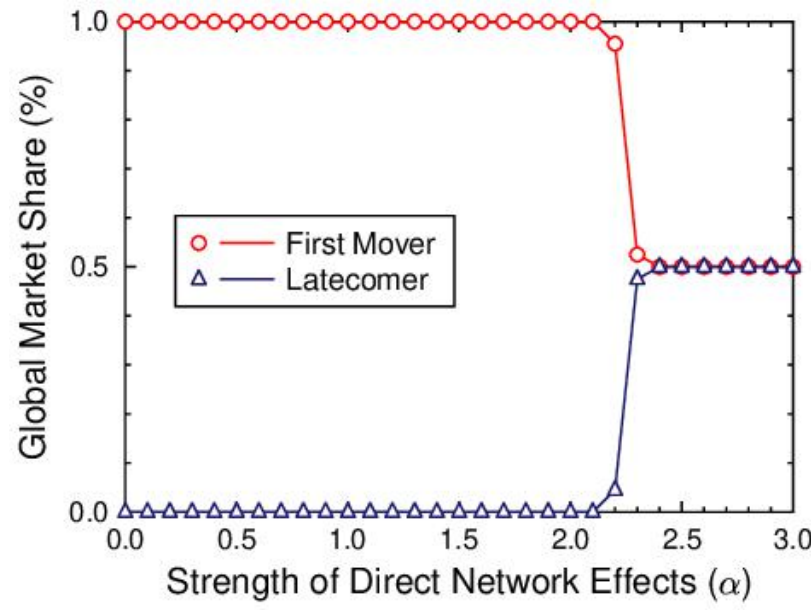

Note: When consumers are more reluctant to adopt a new digital service, the latecomer takes more time to attract users in the foreign country. Thus, the survival regime for the latecomer with early internationalization shrinks. 
Panel C. When there are fewer early adopters $(\mu=400 ; \sigma=280)$

(i) Late Domestic Entry

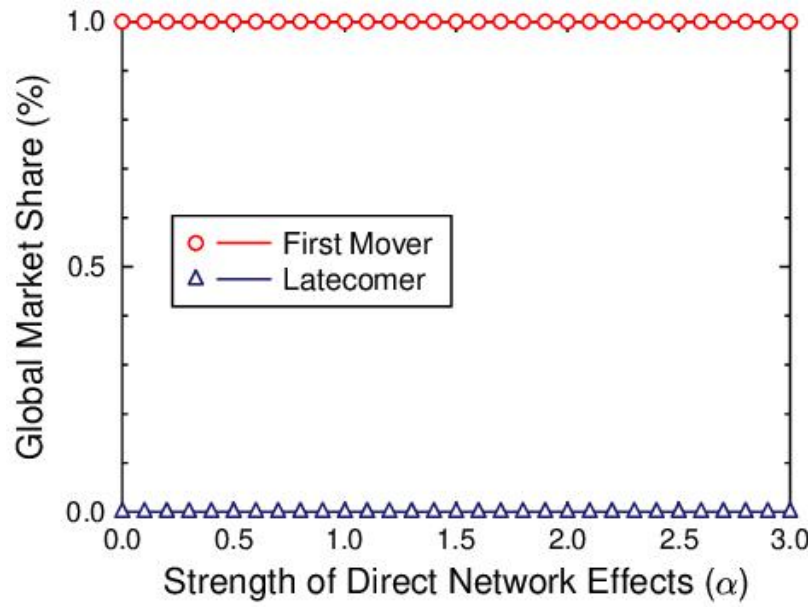

(ii) Early Internationalization

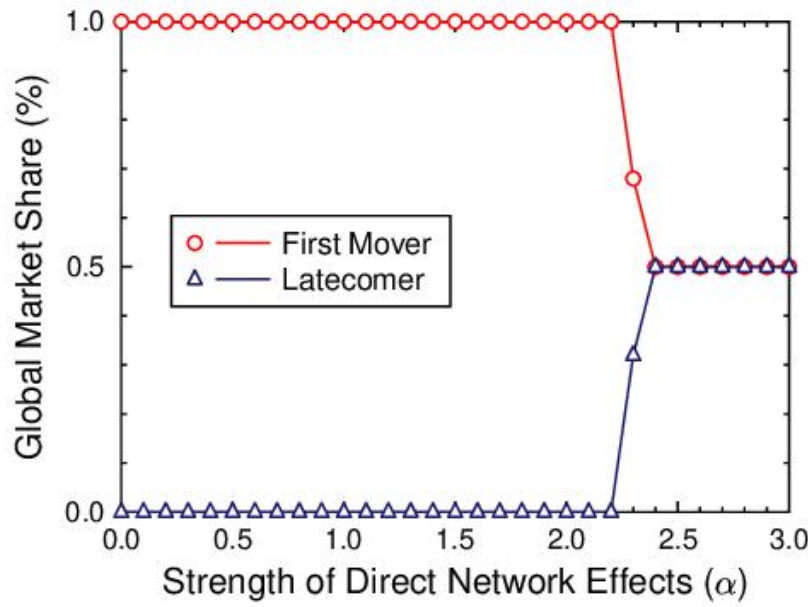

Note: When there are fewer early adopters, the latecomer takes more time to attract users in the foreign country. Thus, the survival regime for the latecomer with early internationalization shrinks.

Panel D. When there are more early adopters $(\mu=400 ; \sigma=320)$

(i) Late Domestic Entry

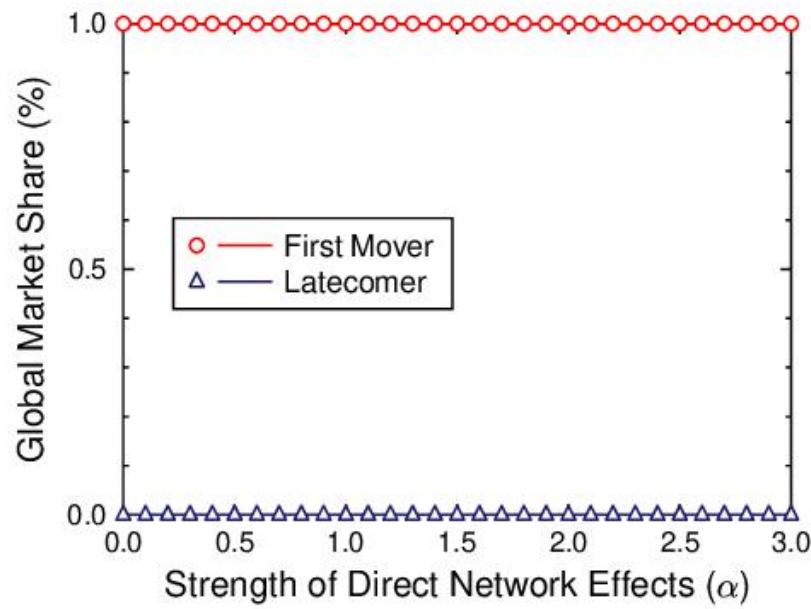

(ii) Early Internationalization

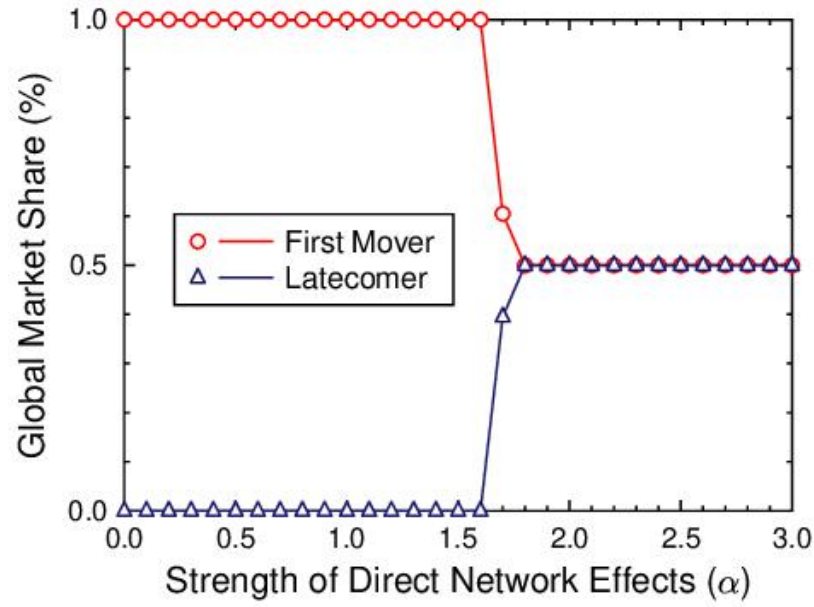

Note: When there are more early adopters, the latecomer takes less time to attract users in the foreign country. Thus, the survival regime for the latecomer with early internationalization expands. 